\title{
Effect of Strongly Bound Copper Species in Copper-Ceria Catalyst for Preferential Oxidation of Carbon Monoxide
}

Pei-Pei Du ${ }^{\mathrm{a}}$, Wei-Wei Wang ${ }^{\mathrm{b}}$, Chun-Jiang Jia ${ }^{\mathrm{b}, *}$, Qi-Sheng Song ${ }^{\mathrm{b}}$, Yu-Ying Huang ${ }^{\mathrm{a}}$,

Rui $\mathrm{Si}^{\mathrm{a}}{ }^{*}$

${ }^{a}$ Shanghai Synchrotron Radiation Facility, Shanghai Institute of Applied Physics, Chinese Academy of Sciences, Shanghai 201204, China

${ }^{\mathrm{b}}$ Key Laboratory for Colloid and Interface Chemistry, Key Laboratory of Special Aggregated Materials, School of Chemistry and Chemical Engineering, Shandong University, Jinan 250100, China 


\section{Abstract}

Copper-ceria catalysts with the $\mathrm{Cu}$ contents up to 40 at.\% were prepared by the coprecipitation method. Ammonium carbonate was used as the leaching agent on the as-calcined samples to remove the weakly bound copper species. The parent and leached catalysts were tested for the preferential oxidation of carbon monoxide (CO-PROX) reaction from 40 to $200{ }^{\circ} \mathrm{C}$ in $1 \% \mathrm{CO} / 1 \% \mathrm{O}_{2} / 50 \% \mathrm{H}_{2} / \mathrm{N}_{2}$ with a space velocity of $60,000 \mathrm{~mL} \cdot \mathrm{h}^{-1} \cdot \mathrm{g}_{\mathrm{cat}}{ }^{-1}$. When the $\mathrm{Cu}$ doping amount reached 30 at.\%, the stable and constant CO-PROX reactivity, including $\mathrm{CO}$ conversion and $\mathrm{O}_{2}$ selectivity, was presented for both parent and ammonium carbonate leached catalysts. The fresh and used samples have been carefully characterized by various techniques such as power X-ray diffraction (XRD), X-ray absorption fine structure (XAFS), transmission electron microscopy (TEM), X-ray Photoelectron Spectroscopy (XPS) and temperature-programmed reduction by hydrogen $\left(\mathrm{H}_{2}\right.$-TPR). It was confirmed that there are two different types of copper species, i. e. weakly bound $\mathrm{CuO}_{x}$ clusters and strongly bound $\mathrm{Cu}-\left[\mathrm{O}_{x}\right]-\mathrm{Ce}$ structure, in both parent and leached catalysts. Furthermore, we have demonstrated that the weakly bound $\mathrm{CuO}_{x}$ clusters removed by ammonium carbonate can be recovered by the migration of $\mathrm{Cu}-\left[\mathrm{O}_{x}\right]-\mathrm{Ce}$ species under the reduction or reaction conditions. The strongly bound copper species in $\mathrm{CeO}_{2}$ have been identified to be the reservoir for the active $\mathrm{Cu}$ sites for CO-PROX.

Keywords: Copper-Ceria; Preferential Oxidation of Carbon Monoxide; Ammonium Carbonate Leaching; X-ray Absorption Fine Structure; Coprecipitation 


\section{Introduction}

Currently, clean and efficient energy has been attracted much interest in catalysis. Hydrogen $\left(\mathrm{H}_{2}\right)$ in the polymer exchange membrane fuel cells (PEMFCs) has been considered as a good candidate for new energy source. However, a small amount $(0.3-1 \%)$ of carbon monoxide $(\mathrm{CO})$ remained in the $\mathrm{H}_{2}$ inlets is severely poisonous to the platinum catalyst used for the electrode materials in PEMFCs [1-3]. Technically, the preferential oxidation of carbon monoxide (CO-PROX) reaction is required to eliminate the toxic $\mathrm{CO}$ gas in the hydrogen source after the water-gas shift (WGS) step [4-7]. Besides the diverse noble metal catalysts such as Pt [8-10], Au [11-13], $\mathrm{Ru}$ [3], ceria $\left(\mathrm{CeO}_{2}\right)$ supported copper oxide $(\mathrm{CuO})$ has been selected for $\mathrm{CO}-\mathrm{PROX}$ [14-16], because of its high reactivity on both $\mathrm{CO}$ conversion and $\mathrm{O}_{2}$ selectivity, as well as the much lower cost than the noble metal catalysts [17-19].

Various solution-based preparation methods including incipient wetness impregnation [20,21], coprecipitation [20,22] and deposition-precipitation [13,23] have been investigated for the copper-ceria catalysts, leading to the different structural and textural properties in the $\mathrm{Cu}-\mathrm{Ce}-\mathrm{O}$ system. The as-prepared copper oxide phase was either dispersed onto the surface of $\mathrm{CeO}_{2}$ support $[16,21,24]$, or the $\mathrm{Cu}^{2+}$ ions were fully or partially (dependent upon the copper amount) doped into the ceria lattice to substitute the $\mathrm{Ce}^{4+}$ sites $[21,23]$. On the other hand, to understand the effects of different types of copper species in ceria, some chemical routes, e. g. the use of leaching agent (cyanide [25], sodium hydroxide [26], sulfuric acid [27] or ammonium carbonate [23]), have been widely used to obtain the leached samples and compared 
the related results of structural characterization and catalytic test to their parent catalysts.

Meanwhile, multiple characterization skills such as X-ray diffraction (XRD) [28,29], X-ray absorption fine structure (XAFS) [30,31], transmission electron microscope (TEM) [32,33], X-ray photoelectron spectroscopy (XPS) [13,24], and diffuse reflectance infrared Fourier transform spectroscopy (DRIFTS) [34], have been extensively applied to the copper-ceria catalysts, either before/after the reaction, or in-situ under the CO-PROX working conditions. By the help of these advanced techniques, the bulk and surface structures of copper on ceria $\left(\mathrm{CuO}_{x} / \mathrm{CeO}_{2}\right)$ or copper-doped ceria $\left(\mathrm{Ce}_{1-x} \mathrm{Cu}_{x} \mathrm{O}_{2-y}\right)$ have been discovered and correlated to the corresponding reactivity for the studied reactions. These techniques are very helpful to determine the active sites and reaction mechanisms for the copper-ceria CO-PROX catalysts. Among them, XAFS, an elemental-sensitive means, is unique to bypass other effects from the ceria support and extract the structural information on the specific $\mathrm{Cu}$ sites. XAFS includes two spectrum ranges, i. e. X-ray absorption near edge spectroscopy (XANES) for electronic structure (oxidation state of $\mathrm{Cu}^{0} / \mathrm{Cu}^{+} / \mathrm{Cu}^{2+}$ and charge transfer between metal-metal or metal-oxygen atoms) [34] and extended X-ray absorption fine structure (EXAFS) for short-range $(<6-8 \AA)$ local structure (coordination number, bond distance and D.W. factor of $\mathrm{Cu}-\mathrm{O}$ and $\mathrm{Cu}-\mathrm{Cu} / \mathrm{Cu}-\mathrm{Ce}$ shells) $[35,36]$.

Furthermore, according to the previous findings on the reducibility of copper-ceria catalyst, the related oxidized copper species synthesized by different 
methods (coprecipitation, deposition-precipitation, etc.) usually include multiple structures, such as isolated $\mathrm{CuO}$ particles, weakly bound $\mathrm{CuO}_{x}$ clusters, strongly bound $\mathrm{Cu}-\left[\mathrm{O}_{x}\right]-\mathrm{Ce}$ and $\mathrm{Cu}^{2+}$ ion in the $\mathrm{CeO}_{2}$ lattice [37]. By the in-situ XAFS measurements, we have previously demonstrated that the weakly bound $\mathrm{CuO}_{x}$ clusters are active species for the CO-PROX reaction [38]. However, the effect of strongly bound copper species is unknown, the contribution of which to the CO-PROX reactivity is still to be explored.

Therefore, in this work, we tried to distinguish the contributions of the above different types of copper species for CO-PROX, with the aid of ammonium carbonate leaching process, which effectively removes the weakly bound $\mathrm{CuO}_{x}$ clusters from the doped $\mathrm{CeO}_{2}$ surface. In experiments, both parent and leached samples have been tested under the CO-PROX reaction conditions in the temperature range $40-200{ }^{\circ} \mathrm{C}$, and further characterized by XRD, XAFS, TEM, XPS and $\mathrm{H}_{2}$-TPR, either before or after the catalytic tests. Based on the results of structural characterization and catalytic tests, we confirmed that the strongly bound $\mathrm{Cu}-\left[\mathrm{O}_{x}\right]-\mathrm{Ce}$ species in $\mathrm{CeO}_{2}$ can act as the reservoir for the active sites for CO-PROX through the migration onto the surface of the catalyst.

\section{Experimental}

\subsection{Catalyst synthesis}

All the chemicals used in this work were of analytical grade and purchased from 
Sinopharm Chemical Reagent Co., Ltd without any further purification.

The copper-ceria catalysts with different $\mathrm{Cu}$ contents were prepared by the coprecipitation method accordingly to the following procedures: (1) $\mathrm{Ce}\left(\mathrm{NO}_{3}\right)_{3} \cdot 6 \mathrm{H}_{2} \mathrm{O}$ and $\mathrm{Cu}\left(\mathrm{NO}_{3}\right)_{2} \cdot 3 \mathrm{H}_{2} \mathrm{O}$ with a total metal amount of $50 \mathrm{mmol}$ were dissolved in $35 \mathrm{~mL}$ Millipore water (18.25 M $\Omega$ ) and stirred for $15 \mathrm{~min}$ at room temperature to form stock solution; (2) The above stock solution was controllably injected into $35 \mathrm{~mL} \mathrm{NaOH}$ $(0.5 \mathrm{~mol} / \mathrm{L})$ solution under vigorously stirring with a constant rate of $0.2 \mathrm{~mL} / \mathrm{min}$ by a mechanically pumping syringe system; (3) After the generation of greenish slurries, the stock solution was further aged at $80{ }^{\circ} \mathrm{C}$ for $4 \mathrm{~h}$; (4) The as-obtained precipitates were filtered and washed by Millipore water until the final $\mathrm{pH}$ value reached 7.0 approximately. Then, the as-washed product was dried in vacuum at $80{ }^{\circ} \mathrm{C}$ overnight, and then air-calcined at $500{ }^{\circ} \mathrm{C}$ for $4 \mathrm{~h}$ with a ramping rate of $2{ }^{\circ} \mathrm{C} / \mathrm{min}$. In this work, the copper-ceria samples were donated as $\boldsymbol{x} \mathbf{C u}(x=5,15,30$ and 40), where $x$ is the copper content in atomic percent $(x=[\mathrm{Cu} /(\mathrm{Cu}+\mathrm{Ce})] \times 100$ at.\% $)$.

For the leaching process, $1.0 \mathrm{~g}$ of the parent copper-ceria catalysts after air-calcination were washed by $50 \mathrm{~mL}$ ammonium carbonate $\left[\left(\mathrm{NH}_{4}\right)_{2} \mathrm{CO}_{3}, 1 \mathrm{~mol} / \mathrm{L}\right]$ aqueous solution for $4 \mathrm{~h}$ at room-temperature under stirring. Then, the as-leached solids were acquired by the sequential filtration, water-washing $(\mathrm{pH}=7)$, drying (vacuum, $80{ }^{\circ} \mathrm{C}$, overnight), and air-calcination $\left(300{ }^{\circ} \mathrm{C}\right.$ for $\left.4 \mathrm{~h}, 2^{\circ} \mathrm{C} / \mathrm{min}\right)$ steps. The ammonia leached samples were denoted as $\boldsymbol{x} \mathbf{C u}-\boldsymbol{L}(x=5,15,30$ and 40). 


\subsection{Characterizations}

The copper loading concentrations $\left(\mathrm{Cu}_{b u l k}\right.$ in at. \%) were determined by inductively coupled plasma atomic emission spectroscopy (ICP-AES) on an IRIS Intrepid II XSP instrument (Thermo Electron Corporation).

The powder X-ray diffraction (XRD) patterns were recorded on a Burker D8 Advance diffractometer $(40 \mathrm{kV}, 40 \mathrm{~mA})$ with a scanning rate of $4^{\circ} \min ^{-1}$, using $\mathrm{Cu} K_{\alpha}$ radiation $(\lambda=1.5406 \AA)$. The corresponding XRD patterns were collected from 20 to $70^{\circ}$ with a step of $0.02^{\circ}$. The $2 \theta$ angles were calibrated with a $\mu \mathrm{m}$-scale Alumina disc. The powder catalyst after grinding was placed inside a quartz-glass sample holder for each test. With the software "LAPOD" of least-squares refinement of cell dimensions from powder data by Cohen's Method $[39,40]$.

The nitrogen adsorption-desorption measurements were performed on a Builder SSA-4200 unit instrument at $77 \mathrm{~K}$. All the copper-ceria samples were degassed at 150 ${ }^{\circ} \mathrm{C}$ under vacuum for over $6 \mathrm{~h}$. The BET specific surface areas $\left(S_{\mathrm{BET}}\right)$ were calculated from the adsorption data in the relative pressure range between 0.05 and 0.20.

The transmission electron microscopy (TEM) and high-resolution TEM (HRTEM) experiments were carried out on a Philips Tecnai $\mathrm{G}^{2} \mathrm{~F} 20$ instrument at $200 \mathrm{kV}$. All the tested samples were sonicated in ethanol about $10 \mathrm{~min}$, and then a drop of this dispersed suspension was placed on an ultra-thin (3 5 $\mathrm{nm}$ in thickness) carbon film-coated Mo grid. The as-formed sample grid was dried naturally under ambient conditions before inserted into the sample holder. High-angle annular dark-field 
scanning transmission electron microscopy (HAADF-STEM) mode with energy dispersive spectroscopy (EDS) was applied for the corresponding elemental mapping to obtain the spatial distribution of $\mathrm{Cu}$ and $\mathrm{Ce}$ in microdomain.

The X-ray absorption fine structure (XAFS) spectra at Cu K-edge $\left(E_{0}=8979 \mathrm{eV}\right)$ were performed at BL14W1 beam line of Shanghai Synchrotron Radiation Facility (SSRF) operated at $3.5 \mathrm{GeV}$ under "top-up" mode with a constant current of $240 \mathrm{~mA}$. The XAFS data were recorded under transmission mode for high $\mathrm{Cu}$ concentrations (30-40 at. \%) with high-flux ion chambers or fluorescence mode for low $\mathrm{Cu}$ concentrations (5-15 at. \%) with standard Lytle ion chamber, respectively. The energy was calibrated accordingly to the absorption edge of pure $\mathrm{Cu}$ foil. Athena and Artemis codes were used to extract the data and fit the profiles. For the X-ray absorption near edge structure (XANES) part, the experimental absorption coefficients as function of energies $\mu(E)$ were processed by background subtraction and normalization procedures, and reported as "normalized absorption". Based on the normalized XANES profiles, the molar fraction of $\mathrm{Cu}^{2+} / \mathrm{Cu}^{+} / \mathrm{Cu}^{0}$ can be determined by the linear combination fit $[38,41]$. For the extended X-ray absorption fine structure (EXAFS) part, the Fourier transformed (FT) data in $R$ space were analyzed by applying $1^{\text {st }}$ shell approximation or metallic $\mathrm{Cu}$ model for the $\mathrm{Cu}-\mathrm{O}$ or $\mathrm{Cu}-\mathrm{Cu}$ shell, respectively. The passive electron factors, $S_{0}^{2}$, were determined by fitting the experimental $\mathrm{Cu}$ foil data and fixing the $\mathrm{Cu}-\mathrm{Cu}$ coordination number $(\mathrm{CN})$ to be 12 , and then fixed for further analysis of the measured samples. The parameters describing the electronic properties (e.g., correction to the photoelectron energy origin, $E_{0}$ ) and local structure 
environment including CN, bond distance (R) and Debye Waller (D.W.) factor around the absorbing atoms were allowed to vary during the fit process. The fitted ranges for $k$ and $R$ spaces were selected to be $k=2.4-12.0 \AA^{-1}$ and $R=1.1-2.1(\mathrm{Cu}-\mathrm{O})$ or $1.7-2.7(\mathrm{Cu}-\mathrm{Cu}) \AA\left(k^{3}\right.$ weighted $)$, respectively.

X-ray photoelectron spectroscopy (XPS) analysis was performed on an Axis Ultra XPS spectrometer (Kratos, U.K.) with $225 \mathrm{~W}$ of $\mathrm{Al} K_{\alpha}$ radiation. The $\mathrm{C} 1 \mathrm{~s}$ line at $284.8 \mathrm{eV}$ was used to calibrate the binding energies. The surface copper concentrations $\left(\mathrm{Cu}_{\text {surf }}\right.$ in at. \%) were determined by integrating the areas of $\mathrm{Cu} 2 \mathrm{p}$ and Ce $3 \mathrm{~d}$ peaks in the CasaXPS software. The fit on specific peaks in each Ce $3 \mathrm{~d}$ spectrum to obtain the relative ratio of $\mathrm{Ce}^{3+} / \mathrm{Ce}^{4+}$ was carried out accordingly to this equation: $\mathrm{Ce}^{3+} / \mathrm{Ce}^{4+}=\mathrm{S} v^{\prime} /\left(\mathrm{S} v^{\prime \prime}+\mathrm{S}\left(v^{0}, v\right)\right)$, where $\mathrm{S} v$ ', $\mathrm{S} v^{\prime \prime}$ and $\mathrm{S}\left(v^{0}, v\right)$ stand for the peak area of $v^{\prime}, v^{\prime \prime}$ and $\left(v^{0}, v\right)$, respectively $[42,43]$.

\subsection{Catalytic tests}

The temperature-programmed reduction by hydrogen $\left(\mathrm{H}_{2}-\mathrm{TPR}\right)$ was performed in a Builder PCSA-1000 instrument equipped with a thermal conductivity detector (TCD). The reduction process was carried out in a mixture of $5 \% \mathrm{H}_{2} / \mathrm{Ar}(30 \mathrm{~mL} / \mathrm{min})$ from room-temperature to $400{ }^{\circ} \mathrm{C}\left(5^{\circ} \mathrm{C} \mathrm{min}^{-1}\right)$. The sieved catalysts (40-60 mesh, 30 mg) were pretreated in pure $\mathrm{O}_{2}$ at $300{ }^{\circ} \mathrm{C}$ for $30 \mathrm{~min}$ before each test.

The CO-PROX reactivity was taken with a plug-flow reactor loaded with ca. 50 mg of sieved catalyst (40-60 mesh) in a gas mixture of $1 \% \mathrm{CO} / 1 \% \mathrm{O}_{2} / 50 \% \mathrm{H}_{2} / \mathrm{N}_{2}$ with 
a space velocity of $60,000 \mathrm{~mL} \cdot \mathrm{h}^{-1} \cdot \mathrm{g}_{\mathrm{cat}}{ }^{-1}$. Before each run, the investigated sample was flowed for $30 \mathrm{~min}$ with oxidative $\left(20 \% \mathrm{O}_{2} / \mathrm{N}_{2}\right)$ atmospheres at $300{ }^{\circ} \mathrm{C}$. For a typical catalytic test, the temperature of copper-ceria sample was heated from 40 to $200{ }^{\circ} \mathrm{C}$ $\left(20{ }^{\circ} \mathrm{C}\right.$ per step) and was stabilized at each temperature plateau under the same reaction conditions for $40 \mathrm{~min}$ to reach the equilibrium. The compositions of the effluent gases were measured with an on-line gas chromatograph (GC 9160 series) equipped with a thermal conductivity detector. The $\mathrm{CO}$ conversion and $\mathrm{O}_{2}$ selectivity were calculated according to the following equations $[38,44]$ :

$\mathrm{CO}$ conversion $(\%)=\left(\mathrm{CO}_{\text {in }}-\mathrm{CO}_{\text {out }}\right) / \mathrm{CO}_{\text {in }} * 100$

$\mathrm{O}_{2}$ selectivity $(\%)=0.5 *\left(\mathrm{CO}_{\text {in }}-\mathrm{CO}_{\text {out }}\right) /\left(\mathrm{O}_{2, \text { in }}-\mathrm{O}_{2, \text { out }}\right) * 100$

The copper-ceria samples after reaction were exposed to atmospheric air without any protection action (e. g. surface passivation to avoid reoxidation of used catalysts) prior to the corresponding characterizations of XRD, TEM/HRTEM, XAFS and XPS.

\section{Results}

\subsection{Synthesis and CO-PROX reactivity of copper-ceria catalyst}

The ICP-AES characterization was conducted to identify the bulk $\mathrm{Cu}$ concentrations in both parent and ammonium carbonate leached copper-ceria samples. Table 1 shows that the determined $\mathrm{Cu}_{\text {bulk }}$ numbers were close to the designed values in all the parent catalysts from $\mathbf{5 C u}$ to $40 \mathbf{C u}$, revealing that the successful 
coprecipitation preparation for the $\mathrm{Cu}$-loading implementation. After the ammonium carbonate leaching, the loss percentage for $\mathrm{Cu}_{b u l k}$ significantly increased from $\mathbf{5 C u} / \mathbf{5 C u}-\boldsymbol{L}(6.5$ at. $\% \rightarrow 5.6$ at. $\%, 14 \%$ loss $)$ to $\mathbf{4 0 C u} / \mathbf{4 0 C u}-\boldsymbol{L}(46.3$ at. $\% \rightarrow 31.3$ at. $\%, 32 \%$ loss), possibly due to the weaker interaction between $\mathrm{CuO}_{x}$ and $\mathrm{CeO}_{2}$ for the samples with higher copper contents.

The catalytic reactivity of the copper-ceria catalysts were measured for $\mathrm{CO}-\mathrm{PROX}$ in $1 \% \mathrm{CO} / 1 \% \mathrm{O}_{2} / 50 \% \mathrm{H}_{2} / \mathrm{N}_{2}$ with a space velocity of $60,000 \mathrm{~mL} \cdot \mathrm{h}^{-1} \cdot \mathrm{g}_{\text {cat }}{ }^{-1}$ and the reaction temperatures from 40 to $200{ }^{\circ} \mathrm{C}$ (see Figure 1). In this work, the overall evolution observed in the $\mathrm{CO}_{2}$ selectivity, also the $\mathrm{CO}$ conversions displaying a maximum at intermediate reaction temperatures originates from the competition between combustion reactions of both $\mathrm{CO}$ oxidation and $\mathrm{H}_{2}$ oxidation [45]. Figure 1 exhibits the distinct differences on both $\mathrm{CO}$ conversions and $\mathrm{O}_{2}$ selectivities between the parent and leached catalysts with the low $\mathrm{Cu}$ doping amounts (see Figure 1a and $1 \mathrm{~b}$ for $\mathbf{5 C u} / \mathbf{5 C u}-\boldsymbol{L}$ and $\mathbf{1 5 C u} / \mathbf{1 5 C u}-\boldsymbol{L}$ ). However, as the copper concentration increased to 30-40 at.\%, almost identical reactivity was displayed in Figure 1c and 1d. Thus, the ammonium carbonate leaching can be used to distinguish the different reactivity contributions from the different copper species.

From Figure 1, we also observed that the CO-PROX reactivity increased with the $\mathrm{Cu}$ doping amount. For instance, the $\mathrm{CO}$ conversion $/ \mathrm{O}_{2}$ selectivity of each sample at $100{ }^{\circ} \mathrm{C}$ follows this order: $\mathbf{5 C u}-\boldsymbol{L}(19 \% / 77 \%)<\mathbf{5 C u}(34 \% / 96 \%)<\mathbf{1 5 C u}-\boldsymbol{L}$ $(78 \% / 80 \%) \approx \mathbf{1 5 C u}(64 \% / 91 \%)<\mathbf{3 0 C u}-\boldsymbol{L}(88 \% / 84 \%) \approx \mathbf{3 0 C u}(84 \% / 91 \%) \approx 4 \mathbf{C u}-\boldsymbol{L}$ $(90 \% / 82 \%) \approx 40 \mathrm{Cu}(83 \% / 88 \%)$. It seems that the max reactivity appeared when the 
copper concentration reached 30 at. $\%$, and the extra $\mathrm{Cu}$ cannot promote the CO-PROX reactivity furthermore.

\subsection{Structure and texture of copper-ceria catalyst}

Powder XRD was applied to determine the bulk structure of the copper-ceria catalysts. Figure 2 a represents the diffraction patterns of both parent and ammonium carbonate leached samples after air-calcination. A cubic Fluorite $f c c \mathrm{CeO}_{2}$ (JCPDS card no.: 34-394) structure can be distinctly confirmed for each catalyst. The broadening of diffraction peaks indicates the nanocrystalline nature of fresh materials. $\mathrm{No} \mathrm{Cu} / \mathrm{Cu}_{2} \mathrm{O} / \mathrm{CuO}$ phases were detected for the copper-ceria catalysts up to 30 at.\% $\mathrm{Cu}$. However, for $\mathbf{4 0 C u}$, the minor diffraction peaks of monoclinic $\mathrm{CuO}$ (JCPDS card no.: 48-1548) located at ca. $35.6^{\circ}$ and $38.7^{\circ}$ were observed, owing to the segregation of extra copper species on the surface of doped ceria.

Table 1 shows that the BET specific surface area $\left(S_{\mathrm{BET}}\right)$ of $\mathbf{4 0 C u}\left(98 \mathrm{~m}^{2} / \mathrm{g}\right)$ was obviously lower than the other copper-ceria samples $\left(110-138 \mathrm{~m}^{2} / \mathrm{g}\right)$, possibly due to the over coverage of $\mathrm{CuO}$ species on the $\mathrm{CeO}_{2}$ surface. By ammonium carbonate leaching, the related XRD patterns in Figure 2a exhibit that $40 \mathrm{Cu}-\boldsymbol{L}$ contained the separated $\mathrm{CuO}$ structure, but with lower fraction than the parent catalyst $(\mathbf{4 0 C u})$. This can be explained by the removal of surface $\mathrm{CuO}$ species during leaching. The XRD results were consistent with the recovery of $S_{\mathrm{BET}}$ for the leached sample $(\mathbf{4 0 C u}-\mathbf{L}, 129$ $\left.\mathrm{m}^{2} / \mathrm{g}\right)$ 
Figure $2 \mathrm{~b}$ shows the XRD patterns of used catalysts after CO-PROX. Only crystallized $\mathrm{CeO}_{2}$ structure was identified for 5-30 at.\% Cu. As for $\mathbf{4 0 C u}$ and $\mathbf{4 0 C u}-\boldsymbol{L}$, metallic copper (JCPDS card no.: 4-836) appeared with the diffraction peaks at $43.3^{\circ}$ and $50.4^{\circ}$. The formation of $\mathrm{Cu}(0)$ can be attributed by the reduction of isolated $\mathrm{CuO}$ phase in the fresh samples under the CO-PROX conditions with high concentration (50\%) of $\mathrm{H}_{2}$ in the reaction gas.

The TEM and HRTEM experiments were carried out to investigate the morphologies (size and shape) of the copper-ceria catalysts. Figure 3 display that all the samples are highly uniform nanocrystals with averaged particle size of 3.5-5.2 nm. From Table 1, it is known that size-distribution is rather narrow (ca. 15\% standard deviation) for each sample. Interestingly, the low-magnification TEM images show the tendency that these nanocrystals were fused between each other as the $\mathrm{Cu}$ concentration increased (from Figure 3a to Figure 3h). It is probably because of the doping effect when the second metal ion was introduced into the ceria support. Besides, the XRD-visible $\mathrm{CuO}$ phase was undistinguishable in TEM/HRTEM for $40 \mathrm{Cu}$ and $40 \mathrm{Cu}-\boldsymbol{L}$, due to its trace of amount, also the possibly similar morphology to that of $\mathrm{Cu}-\mathrm{Ce}-\mathrm{O}$ nanocrystals.

Figure 4 exhibits the TEM/HRTEM images of the used catalysts. Table 1 shows that the particle size $(3.6-5.1 \mathrm{~nm})$ and shape (polyhedron w/o fusion) were similar to the corresponding fresh samples up to 30 at.\% $\mathrm{Cu}$. It demonstrates that the CO-PROX reaction was conducted at lower temperatures $\left(<200^{\circ} \mathrm{C}\right)$ than those of air-calcination $\left(500{ }^{\circ} \mathrm{C}\right)$. So the morphology of copper-doped ceria nanocrystals was maintained. Big 
$\mathrm{Cu}$ particles were confirmed for used 40Cu (30-60 nm) and 40Cu- $\boldsymbol{L}(10-25 \mathrm{~nm})$, which is in good agreement with the XRD data (see Figure 2b). The segregated CuO structure underwent severe reduction process and sequential crystal growth during CO-PROX.

To verify the homogeneity of the copper-ceria catalysts other than 40 at.\% $\mathrm{Cu}$, we applied the HAADF-STEM with EDS (spot size: ca. $2 \mathrm{~nm}$ ) to conduct the elemental mapping analysis. From Figure 5 we can easily see that both $\mathrm{Cu}$ and $\mathrm{Ce}$ component were homogenously dispersed for $30 \mathrm{Cu}$ and $30 \mathrm{Cu}-\boldsymbol{L}$ before and after the CO-PROX reaction. No $\mathrm{Cu}$-rich region was detected in HAADF-STEM/EDS, revealing the uniform dispersion of copper in the ceria support at the nanometer scale. However, no direct observations on the atomic dispersion of $\mathrm{Cu}$ over the oxide matrix have been obtained. Therefore, we cannot demonstrate the homogeneous doping of copper into ceria via coprecipitation synthesis in this work.

Based on the above characterization data on ICP-AES, BET, XRD, TEM/HRTEM and HAADF-STEM/EDS, we can draw a conclusion that the copper-ceria catalysts by coprecipitation could be assign to solid solutions with the formula of $\mathrm{Ce}_{1-x} \mathrm{Cu}_{x} \mathrm{O}_{2-y}(x=0-0.3)$ for 5-30 at.\% Cu . However, the changes of $\mathrm{CeO}_{2}$ cell dimension with the bulk $\mathrm{Cu}$ values in Figure 6 do not obey the Vegard's law. The calculated $a$ value is either constant or increased with the bulk $\mathrm{Cu}$ concentration, which is due to the synergetic effects between the aliovalent doping effect and the size effect in $\mathrm{Cu}-\mathrm{Ce}-\mathrm{O}$ system [37]. To justify this assumption, we have determined the decrease of averaged particle size with the copper doping amount for both parent 
(Figure 6a) and ammonium carbonate leached samples (Figure 6b), because of size effect.

\subsection{Copper species in copper-ceria catalyst}

The conventional characterizations give the general structural information for the $\mathrm{Cu}-\mathrm{Ce}-\mathrm{O}$ catalysts. However, the specific structure around the measured copper atoms, which are very important to identify the active $\mathrm{Cu}$ site, was missing. Here, XAFS technique was used to investigate the structure in the copper-ceria catalysts with different $\mathrm{Cu}$ contents, which is elemental sensitive and very powerful to determine the electronic and local structure of metals. In XANES region, the edge energy, the white line intensity and the pre-edge features are related to the oxidation state of $\mathrm{Cu}^{2+} / \mathrm{Cu}^{+} / \mathrm{Cu}^{0}$. Compared to XPS, XANES test can be conducted under milder ambient conditions. Besides, it has been reported that the $\mathrm{Cu}^{0}$ and $\mathrm{Cu}^{+}$species cannot be easily distinguished by the regular XPS measurement $[46,47]$. Thus, we selected the XANES approach to identify the oxidation states of copper in this work.

The $\mathrm{Cu}$ K-edge XANES spectrum of copper-ceria catalysts is compared with those of $\mathrm{Cu}$ foil, $\mathrm{Cu}_{2} \mathrm{O}$ and $\mathrm{CuO}$ standards in Figure 7. Different edge energies and shapes of the three standards provide vital information on the corresponding oxidation state of copper, which can be better distinguished by linear combination fit $[38,41]$ in Figure S1. The weak pre-edge peak at $8977 \mathrm{eV}$ is ascribed to the dipole-forbidden electronic transition of $1 \mathrm{~s} \rightarrow 3 \mathrm{~d}$ for $\mathrm{Cu}$ (II) [48] and the relatively stronger peaks 
around 8980 and $8983 \mathrm{eV}$ are attributed to the dipole-allowed $1 \mathrm{~s} \rightarrow 4 \mathrm{p}$ electron transition for $\mathrm{Cu}(\mathrm{I})$ and $\mathrm{Cu}(\mathrm{II})$, respectively [49]. Meanwhile, the distinct feature at $8979 \mathrm{eV}$ can be assigned to the unique $\mathrm{Cu}(0)$ structure.

It can be easily identified that pure $\mathrm{Cu}(\mathrm{II})$, without any profiles of $\mathrm{Cu}(\mathrm{I})$ or $\mathrm{Cu}(0)$, appeared for the fresh (parent and leached) copper-ceria catalysts, confirming that the air-calcination at $500{ }^{\circ} \mathrm{C}$ can keep the fully oxidized features for copper. However, the XANES results cannot distinguish between different $\mathrm{Cu}(\mathrm{II})$ dominant species such as the $\mathrm{CuO}$ crystals, the doped $\mathrm{Cu}^{2+}$ ions in the ceria lattice and the weakly/strongly bound surface $\mathrm{CuO}_{x}$ clusters.

Figure 7 and Figure S1 also exhibit the oxidation state of copper after CO-PROX. For low $\mathrm{Cu}$ samples $(\mathbf{5 C u} / \mathbf{5 C u}-\boldsymbol{L}$ and $\mathbf{1 5 C u} / \mathbf{1 5 C u}-\boldsymbol{L})$, copper was kept in the oxidized $\left(\mathrm{Cu}^{2+}\right)$ state even after the CO-PROX reaction in the presence of high concentration $(50 \%) \mathrm{H}_{2}$, demonstrating that copper is strongly interacting with the ceria support. However, for high $\mathrm{Cu}$ samples $(30 \mathrm{Cu} / \mathbf{3 0 C u}-\boldsymbol{L}$ and $40 \mathrm{Cu} / \mathbf{4 0 C u}-\boldsymbol{L})$, copper was partially reduced to $\mathrm{Cu}^{0}$ and $\mathrm{Cu}^{+}$after reaction, revealing that extra isolated copper structure forms besides strong interaction between copper and ceria. The related XRD data only confirm the formation of metallic copper for used $40 \mathrm{Cu}$ and $40 \mathrm{Cu}-\boldsymbol{L}$, indicating that XANES is more sensitive to the non-crystalline copper species in our system.

The $R$ space EXAFS data on the copper-ceria catalysts are presented in Figure 8, together with the corresponding fitting results summarized in Table 2. A strong $\mathrm{Cu}-\mathrm{O}$ 
shell at 1.91-1.94 $\AA$ (phase shift: ca. $0.4 \AA$ in Figure 8 ) was observed for all the samples before and after the CO-PROX test. The fitted coordination number $(\mathrm{CN})$ of $\mathrm{Cu}-\mathrm{O}$ slightly decreased from $\mathbf{5 C u} / \mathbf{5 C u}-\boldsymbol{L}(>3$ ) to $\mathbf{4 0 C u} / \mathbf{4 0 C u}-\boldsymbol{L}$ (around 2.0 for some catalyst), possibly caused by the generation of $\mathrm{CuO}_{x}$ clusters and metallic copper in the fresh and used samples, respectively. Both of these species contain $\mathrm{Cu}-\mathrm{Cu}$ bond if compared to the doped $\mathrm{Cu}^{2+}$ ion, which should only have the $\mathrm{Cu}-\mathrm{O}$ shell in EXAFS. Furthermore, the $\mathrm{CN}$ of $\mathrm{Cu}-\mathrm{O}$ in each copper-ceria catalyst is much smaller than the theoretic value of $\mathrm{Cu}_{x} \mathrm{Ce}_{1-x} \mathrm{O}_{2-y}$ solid solutions $(\mathrm{CN}=6)$. This is consistent with the previous reports on copper-ceria [36], and can be explained by the unsaturated surface of measured nanocrystals in this work. In XANES, metallic $\mathrm{Cu}(0)$ has been identified for the used 15-40 at.\% Cu samples (see Table 2 and Figure S1). However, there is no $\mathrm{Cu}-\mathrm{Cu}(2.5-2.6 \AA)$ structure can be quantitatively fitted in EXAFS (see Figure 8a-8c), except for $\mathbf{4 0 C u} / \mathbf{4 0 C u} \boldsymbol{L}$ which has presented distinct $\mathrm{Cu}-\mathrm{Cu}$ contributions. Thus, the reduced copper metals could be very small (usually < $1 \mathrm{~nm})$ clusters for $15-30$ at. $\% \mathrm{Cu}$ samples.

\subsection{Surface properties and reducibility of copper-ceria catalyst}

The XPS measurement was carried out to investigate the surface $\mathrm{Cu}$ concentration $\left(\mathrm{Cu}_{\text {surf }}\right)$ of catalyst and the calculated $\mathrm{Cu}_{\text {surf }}$ values have been listed in Table 1. The fresh and leached catalysts display lower $\mathrm{Cu}_{\text {surf }}$ values than the corresponding parent samples, revealing that the ammonium carbonate leaching can 
effectively remove the weakly bound copper species on ceria support [37]. Especially for fresh $\mathbf{5 C u} / \mathbf{5 C u}-\boldsymbol{L}$, the $\mathrm{Cu}_{\text {surf }}$ value $(11.2 \% / 9.0 \%)$ was much higher than $\mathrm{Cu}_{\text {bulk }}$ $(6.5 \% / 5.6 \%)$, due to the surface segregation of copper species for low $\mathrm{Cu}$ amount. After the CO-PROX reaction, the $\mathrm{Cu}_{\text {surf }}$ value decreased slightly $(9.5 \% / 7.2 \%)$, but still significantly higher than $\mathrm{Cu}_{\text {bulk }}$.

Starting from $15 \mathrm{Cu} / \mathbf{1 5 C u}-L$, the $\mathrm{Cu}_{\text {surf }}$ values of the fresh copper-ceria catalysts, either parent or ammonium carbonate leached, were very close to $\mathrm{Cu}_{\text {bulk }}$. It reveals the homogenous doping of copper into ceria if the $\mathrm{Cu}$ amount was enough high. As for $40 \mathrm{Cu}$, the $\mathrm{Cu}_{\text {surf }}$ value was obviously higher than $\mathrm{Cu}_{\text {bulk }}$, because of the formation of $\mathrm{CuO}$ phase on the surface of doped ceria. After the reaction, there was a significant increase on $\mathrm{Cu}_{\text {surf }}(18.7-79.4$ at.\%), compared to the fresh sample (15.0-46.3 at.\%). This can be attributed to the migration of doped $\mathrm{Cu}^{2+}$ ion out of the ceria lattice by the reducing atmosphere in $\mathrm{CO}-\mathrm{PROX}$.

The relative ratio of $\mathrm{Ce}^{3+}$ to $\mathrm{Ce}^{4+}$ in each sample was obtained by the peak fits on the XPS spectra of Ce 3d (see Figure S2 for details), and the numeric results have been listed in Table 1 . Generally, the $\mathrm{Ce}^{3+} / \mathrm{Ce}^{4+}$ ratio was slightly increased for the low $\mathrm{Cu}$ samples $(\mathbf{5 C u}: \quad 0.56 \rightarrow 0.63 ; \mathbf{5 C u}-L: \quad 0.60 \rightarrow 0.64 ; \mathbf{1 5 C u}: 0.56 \rightarrow 0.66 ; \mathbf{1 5 C u}-L:$ $0.58 \rightarrow 0.63$ ) after $\mathrm{CO}-\mathrm{PROX}$, while was distinctly raised for the high $\mathrm{Cu}$ samples (30Cu: $0.48 \rightarrow 0.66 ;$ 30Cu- $L: 0.46 \rightarrow 0.65 ;$ 40Cu: $0.39 \rightarrow 0.48 ;$ 40Cu- $L: 0.50 \rightarrow 0.74$ ) after reaction. The formation of $\mathrm{Ce}$ (III) species in the used catalysts can be also verified by the change of lattice constants $(a)$ in copper-doped ceria. Figure $6 \mathrm{a}$ and $6 \mathrm{~b}$ exhibit that the $a$ value is significantly increased after the CO-PROX reaction, 
especially for the high $\mathrm{Cu}$ samples $(30 \mathrm{Cu} / 30 \mathrm{Cu}-\boldsymbol{L}$ and $40 \mathrm{Cu} / 40 \mathrm{Cu}-\boldsymbol{L})$. It can be explained by the fact that smaller $\mathrm{Ce}^{4+}$ ion $(97 \mathrm{pm}, \mathrm{CN}=8)$ is substituted by larger $\mathrm{Ce}^{3+}$ ion $(114 \mathrm{pm}, \mathrm{CN}=8)$.

The reducibility of copper-ceria catalyst was determined by $\mathrm{H}_{2}$-TPR, which can also give important information on the surface oxygen species. Figure 10 exhibits the $\mathrm{H}_{2}$-TPR profiles for both parent and leached samples. It has been reported that pure cerium oxide, even in nanostructured form, cannot be reduced below $300{ }^{\circ} \mathrm{C}$ in $\mathrm{H}_{2}$-TPR [50]. Thus, the $\mathrm{H}_{2}$-TPR peaks in this work should be assigned to the reduction of surface oxygen activated by the copper atoms in ceria. The corresponding hydrogen consumption values, or surface oxygen amounts, were calculated and listed in Table 3. According to the previous results, the reduction of different copper species including isolated $\mathrm{Cu}(\mathrm{II})$ species [37,51], isolated or weakly bound $\mathrm{CuO}$ particles [52-55] and small-size $\mathrm{CuO}$ particles strongly interacting with the ceria surface $[53,54,56]$, highly dispersed copper-oxide clusters [37,54,55] or strongly bound copper oxide species on the ceria support [37,52,], and the $\mathrm{Cu}^{2+}$ ion in the lattice of $\mathrm{CeO}_{2}[37,53]$, have been verified for the $\mathrm{Cu}-\mathrm{Ce}-\mathrm{O}$ system. In this work, two major $\mathrm{H}_{2}$-TPR peaks for the fresh catalysts can be assigned to the low-temperature reduction of weakly bound $\mathrm{CuO}_{x}$ clusters (“A” in Figure 10) and the high-temperature reduction of strongly bound $\mathrm{Cu}-\left[\mathrm{O}_{\mathrm{x}}\right]-\mathrm{Ce}$ structure ("B" in Figure 10), plus a minor shoulder around the low-temperature reduction ("C" in Figure 10) for the ammonium carbonate-leached samples (see Table 3 and Figure S3 for details). However, the reduction of further deep copper species, lattice $\mathrm{Cu}^{2+}$ ions, was not 
observed at the higher temperatures than " $\mathrm{B}$ " [37]. It indicates that the lattice $\mathrm{Cu}^{2+}$ ion may be mixed with the strongly bound copper species and cannot be distinguished between each other in our system.

Previously, ammonium carbonate was considered to be a strong leaching agent for copper [37]. Here, we tried to separate different copper species nanostructures by comparing the reducibility between parent and leached samples. It can be clearly seen from Figure 10 that the $\mathrm{H}_{2}$-TPR peaks of both " $\mathrm{A}$ " and " $\mathrm{B}$ " have been shifted to higher temperatures for the leached low $\mathrm{Cu}$ (5 or 15 at.\%) catalysts, demonstrating the effective removal of weakly bound $\mathrm{CuO}_{x}$ clusters. The non-leachable strongly bound copper species require higher reducing potential (temperature or concentration of $\mathrm{H}_{2}$ ) to be extracted out of the lattice or sublayers of $\mathrm{CeO}_{2}$. Unlike the previous report [37], two reduction peaks were maintained in $\mathrm{H}_{2}$-TPR profiles for our leached catalysts. The low-temperature reduction can be assigned to the weakly bound $\mathrm{CuO}_{x}$ clusters, which were newly generated from the previous strongly bound copper species during the $\mathrm{H}_{2}$-TPR tests. Currently, the reduction peak for strongly bound $\mathrm{Cu}-\left[\mathrm{O}_{x}\right]-\mathrm{Ce}$ structure shifted to higher temperatures for the leached samples. Similar to the previous findings, the reduction temperatures for the high $\mathrm{Cu}$ (30 and 40 at.\%) catalysts were nearly constant before and after the leaching step. It indicates that the strongly bound copper species can migrate onto the $\mathrm{CeO}_{2}$ surface and be converted to the weakly bound $\mathrm{CuO}_{x}$ clusters more easily if the inner copper amount is high.

Table 3 displays the experimental $\mathrm{H}_{2}$ consumption values are significantly higher than the calculated numbers, which only consider the transformation of $\mathrm{CuO}$ to $\mathrm{Cu}$. In 
another word, one copper atom interacts with more than one oxygen atoms, indicating that copper can effectively activate the surface oxygen of ceria support. The total surface oxygen amounts of leached catalysts were kept the same to the parent for low $\mathrm{Cu}(5-15$ at.\%), while distinctly lower than those before leaching for high $\mathrm{Cu}$ (30-40 at.\%). For the specific $\mathrm{H}_{2}$ consumption values contributed by weakly bound $\mathrm{CuO}_{x}$ clusters ("A") and strongly bound $\mathrm{Cu}-\left[\mathrm{O}_{x}\right]-\mathrm{Ce}$ structure ("B") are very similar between parent and leached samples for low $\mathrm{Cu}$, probably because that the residual copper species can activate more oxygen atoms than the ones before ammonium carbonate leaching step. On the other hand, distinctly lower amounts contributed by either peak " $A$ " or peak " $B$ " after the ammonium carbonate step have been determined for high $\mathrm{Cu}$, possibly due to the loss of $\mathrm{Cu}$ content.

\section{Discussion}

By the aids of ICP-AES, XPS, $\mathrm{H}_{2}$-TPR, it has been reported that the oxidized copper species in ceria usually include multiple structures, such as weakly bound $\mathrm{CuO}_{x}$ clusters, strongly bound $\mathrm{Cu}-\left[\mathrm{O}_{x}\right]-\mathrm{Ce}$ and $\mathrm{Cu}^{2+}$ ion in the $\mathrm{CeO}_{2}$ lattice $[13,21,37]$. By the in-situ XAFS measurements, we have previously demonstrated that the weakly bound $\mathrm{CuO}_{x}$ clusters are active species for the CO-PROX reaction [38]. However, it is still unknown for the effect of other copper species. Are they active for CO-PROX or just spectators? In this work, we tried to use ammonium carbonate leaching treatment to study the effect of copper species other than weakly bound $\mathrm{CuO}_{x}$ clusters. 
According to the related XRD, XAFS, TEM, XPS and $\mathrm{H}_{2}$-TPR results discussed in section 3, we now have a full view for the structural evolution on the copper-ceria catalyst by coprecipitation (see Scheme1). First of all, for the parent fresh samples, weakly and strongly bound copper species were identified by $\mathrm{H}_{2}$-TPR. No experimental evidences can be found for the separation between strongly bound $\mathrm{Cu}-\left[\mathrm{O}_{x}\right]-\mathrm{Ce}$ and $\mathrm{Cu}^{2+}$ ion [35] in the $\mathrm{CeO}_{2}$ lattice by $\mathrm{H}_{2}$-TPR. So, the strongly bound copper species in this work included two parts of both in the lattice and on the surface of $\mathrm{CeO}_{2}$.

Upon ammonium carbonate leaching, the XPS characterization confirmed the successful removal of surface copper species. No other differences on the bulk and surface structure between parent and leached catalysts were observed. Also, the related XANES measurements determined that copper was fully oxidized in doped-ceria. Although ammonium carbonate was considered to be a stronger leaching agent for copper species than other chemicals such as sodium cyanide [37], $\mathrm{CuO}$ nanocrystals were still observed in XRD for $40 \mathrm{Cu}-L$. It should be due to the strong interaction between non-leachable $\mathrm{CuO}$ phase and the doped ceria.

However, there are still two (low- and high-temperature) major reduction peaks appeared for the leached catalysts. As for the copper-ceria prepared by the deposition-precipitation method, weakly bound $\mathrm{CuO}_{x}$ clusters were removed by $\mathrm{NaCN}$-leaching and not regenerated for low $\mathrm{Cu}$ samples during $\mathrm{H}_{2}$-TPR [37]. Here, we found that weakly bound copper species can be recovered by the migration of strongly bound $\mathrm{Cu}-\left[\mathrm{O}_{x}\right]-\mathrm{Ce}$ structure from lattice to surface of doped ceria. This 
diffusion needs to meet the following two requirements: (1) There are rich strongly bound copper species in $\mathrm{CeO}_{2}$; (2) The external driving force, i. e. reducing potential (temperature, type and concentration of reducing agent, etc.) must be put onto the strongly bound copper species.

From Figure 10 and Table 3, we also noticed that for low $\mathrm{Cu}$ samples, the reduction peaks in the leached materials $(5 \mathrm{Cu}-\boldsymbol{L}$ and $15 \mathrm{Cu}-\boldsymbol{L})$ are shifted to higher temperatures than the parent catalysts $(\mathbf{5 C u}$ and $\mathbf{1 5 C u})$. This can be explained by the redistribution of copper species by the ammonium carbonate washing [57]. Specifically in this work, when copper is rich, the removal of weakly bound $\mathrm{CuO}_{x}$ clusters by leaching is promptly recovered by the transfer of strongly bound $\mathrm{Cu}-\left[\mathrm{O}_{x}\right]-\mathrm{Ce}$ structure during $\mathrm{H}_{2}$-TPR. Due to the loss of $\mathrm{Cu}$ content during the ammonium carbonate step, the surface oxygen amounts originated from both weakly and strongly bound copper species in the leached samples are lower than those in the parent catalysts. However, when copper is lean, the above transformation happens at higher temperatures than the reduction of weakly bound copper species in the parent catalyst. Furthermore, the residual $\mathrm{Cu}-\left[\mathrm{O}_{x}\right]-\mathrm{Ce}$ species are more difficult to be reduced than the strongly bound species in the parent samples. But the total $\mathrm{H}_{2}$ consumption values are constants before and after the leaching, probably because the residual copper species may activate more oxygen atoms than those in the parent materials.

The third reduction (peak " $\mathrm{C}$ " in Figure 10 and determined by peak-fit in Figure S3) in $\mathrm{H}_{2}$-TPR, other than weakly and strongly bound copper species, was identified for the leached sample. This is actually a minor reduction as a shoulder close to the 
weakly bound $\mathrm{CuO}_{x}$ clusters (peak "A") and could be generated during the migration of strongly bound $\mathrm{Cu}-\left[\mathrm{O}_{x}\right]-\mathrm{Ce}$ species with the gradual reduction in multiple steps, which reveals the complicated structural evolution on active copper sites during either the hydrogen reduction.

Therefore, the strongly bound $\mathrm{Cu}-\left[\mathrm{O}_{x}\right]-\mathrm{Ce}$ structure acts as a reservoir for the weakly bound $\mathrm{CuO}_{x}$ clusters. The strongly bound copper species themselves may not be direct active sites, but can generate the migrated $\mathrm{CuO}_{x}$ source. As long as the copper amount is kept high (ca. 30 at.\% in our work), the reactivity of copper-ceria catalyst will increase continuously until the formation of $\mathrm{CuO}$ phase on the surface of doped ceria. So, the max reactivity for CO-PROX appeared when the $\mathrm{Cu}$ concentration reached 30 at. $\%$.

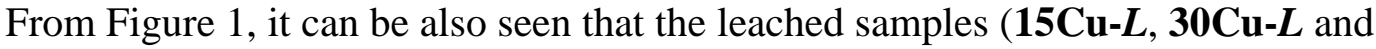
$\mathbf{4 0 C u}-\boldsymbol{L})$ exhibit more $\mathrm{CO}$ conversions than the corresponding parent catalysts $(\mathbf{1 5 C u}$, 30Cu and 40Cu). Similar results have been already reported for copper-ceria system treated with ammonium carbonate [57]. In our work, this phenomenon can also be explained by the redistribution of active species proposed by Mariño et. al. [57], i. e. the improvement of contact between the reacting molecules and the active sites. As discuss as above, such redispersion of active sites could be correlated to the structural evolution on the weakly and strongly bound copper species during the CO-PROX reaction. 


\section{Conclusions}

The copper-ceria catalysts with different $\mathrm{Cu}$ concentrations (5-40 at.\%) were prepared by coprecipitation method. Leaching treatment by $\left(\mathrm{NH}_{4}\right)_{2} \mathrm{CO}_{3}$ was applied to remove the weakly bound $\mathrm{CuO}_{x}$ clusters, and further investigate the effect of strongly bound copper species. Based on the results of XRD and TEM, the uniform copper structure in ceria was obtained for the fresh and used samples of 5-30 at.\% $\mathrm{Cu}$. The high and stable catalytic reactivity appeared for 30 at.\% copper doping. By the XAFS measurements, pure $\mathrm{Cu}(\mathrm{II})$ oxidation states were confirmed for the fresh samples and the metallic copper formed for the catalysts with $30-40$ at.\% $\mathrm{Cu}$ in the used catalysts. By the aids of XPS and $\mathrm{H}_{2}$-TPR, we compared the surface and bulk structure for parent and leached copper-ceria samples and found that the strongly bound $\mathrm{Cu}-\left[\mathrm{O}_{x}\right]$-Ce species provide extra source for the recovery of weakly bound $\mathrm{CuO}_{x}$ clusters, and can be regarded as the reservoir for the surface active copper species during the CO-PROX reaction.

\section{Author Information}

\section{Corresponding Author:}

jiacj@sdu.edu.cn, sirui@sinap.ac.cn

\section{Notes}

The authors declare no competing financial interest. 


\section{Acknowledgement}

Financial supported from the National Science Foundation of China (NSFC) (grant nos. 21373259, 21301107 and 11079005), the Hundred Talents project of the Chinese Academy of Sciences, the Strategic Priority Research Program of the Chinese Academy of Sciences (grant no. XDA09030102), Fundamental research funding of Shandong University (grant nos. 2014JC005), the Taishan Scholar project of Shandong Province (China), Open Funding from Beijing National Laboratory for Molecular Science.

\section{References}

[1] B. Lindström, L.J. Pettersson, Int. J. Hydrog. Energy 26 (2001) 923-933.

[2] M.J. Kahlich, H.A. Gasteiger, R.J. Behm, J. Catal. 182 (1999) 430-440.

[3] Y.F. Han, M.J. Kahlich, M. Kinne, R. Behm, Phys. Chem. Chem. Phys. 4 (2002) 389-397.

[4] S. Monyanon, A. Luengnaruemitchai, S. Pongstabodee, Int. J. Hydrogen Energy 35 (2010) 3234-3242.

[5] T. Caputo, T. Lisi, R. Pirone, G. Russo, Appl. Catal. A 348 (2008) 42-53.

[6] T.V. Choudhary, D.W. Goodman, Catal. Today 77 (2002) 65-78.

[7] P.V. Snytnikov, M.M. Popova, Y. Menc, E.V. Rebrov, G. Kolb, V. Hessel, Appl. Catal. A 350 (2008) 53-62.

[8] M. Kotobuki, A. Watanabe, H. Uchida, H. Yamashita, M. Watanabe, J. Catal. 236 (2005) 262-269.

[9] O. Korotkikh, R. Farrauto, Catal. Today 62 (2000) 249-254.

[10] D.H. Kim, M.S. Lim, Appl. Catal. A 224 (2002) 27-38.

[11] G. Avgouropoulos, T. Ioannides, C. Papadopoulou, J. Batista, S. Hocevar, H.K. Matralis, Catal. Today 75 (2002) 157-167.

[12] P. Landon, J. Ferguson, B.E. Solsona, T. Garcia, A.F. Carley, A.A. Herzing, C.J. Kiely, 
S.E. Golunski, G.J. Hutchings, Chem. Comm. 27 (2005) 3385-3387.

[13] S. Scirè, C. Crisafulli, P.M. Riccobene, G. Patanè, A. Pistone, Appl. Catal. A 417-418 (2012) 66-75.

[14] A. Martinez-Arias, A.B. Hungria, G. Munuera, D. Gamarra, Appl. Catal. B 65 (2006) 207-216.

[15] J. Li, P. Zhu, S. Zuo, Q. Huang, R. Zhou, Appl. Catal. A 381 (2010) 261-266.

[16] Y. Zhang, H. Liang, X.Y. Gao, Y. Liu, Catal. Comm. 10 (2009) 1432-1436.

[17] J.X. Wang, C. Ma, Y.M. Choi, D. Su, Y. Zhu, P. Liu, R. Si, M.B. Vukmirovic, Y. Zhang, R.R. Adzic, J. Am. Chem. Soc. 133 (2011) 13551-13557.

[18] J.D.L. Fonseca, H.S. Ferreira, N. Bion, L. Pirault-Roy, M.D. Rangel, D. Duprez, F. Epron, Catal. Today 180 (2012) 34-41.

[19] B. Qiao, A. Wang, M. Takahashi, Y. Zhang, J. Wang, Y. Deng, T. Zhang, J. Catal. 279 (2011) 361-365.

[20] D. Gamarra, G. Munuera, A.B. Hungría, M. Fernández-García, J.C. Conesa, P.A. Midgley, X.Q. Wang, J.C. Hanson, J.A. Rodríguez, A. Martínez-Arias, J. Phys. Chem. C 111 (2007) 11026-11038.

[21] A.P. Jia, G.S. Hu, L. Meng, Y.L. Xie, J.Q. Lu, M.F. Luo, J. Catal. 289 (2012) 199-209.

[22] A. Aranda, S. Agouram, J.M. López, A.M. Mastral, D.R. Sellick, B. Solsona, S.H. Taylor, T. García, Appl. Catal. B 127 (2012) 77-88.

[23] L. Li, Y. Zhan, Q. Zheng, Y. Zheng, C. Chen, Y. She, X. Lin, K. Wei, Catal. Lett. 130 (2009) 532-540.

[24] E. Moretti, M. Lenarda, P. Riello, L. Storaro, A. Talon, R. Frattini, A. Reyes-Carmona, A. Jiménez-López, E. Rodríguez-Castellón, Appl. Catal. B 129 (2013) 556-565.

[25] Q. Fu, H. Saltsburg, M. Flytzani-Stephanopoulos, Science 301 (2003) 935-938.

[26] S. Abelló, A. Bonilla, J. Pérez-Ramírez, Appl. Catal. A 364 (2009) 191-198.

[27] E.A. Abdel-Aal, M.M. Rashad, Hydrometallurgy 74 (2004) 189-194.

[28] S. Scirè, P.M. Riccobene, C. Crisafulli, Appl. Catal. B 101 (2010) 109-117.

[29] Z. Lendzion-Bielun, M.M. Bettahar, S. Monteverdi, Catal. Comm. 11 (2010) 1137-1142.

[30] X. Wang, J.A. Rodriguez, J.C. Hanson, D. Gamarra, M. Fernandez-Garcia, A. Martinez-Arias, J. Phys. Chem. B 109 (2005) 19595-29603.

[31] J. Ciston, R. Si, J.A. Rodriguez, J.C. Hanson, A. Martínez-Arias, M. Fernandez-García, Y.M. Zhu, J. Phys. Chem. C 115 (2011) 13851-13859.

[32] A. Arango-Díaz, E. Moretti, A. Talon, L. Storaro, M. Lenarda, P. Núñez, J. Marrero-Jerez, J. Jiménez-Jiménez, A. Jiménez-Lópeza, E. Rodríguez-Castellón, Appl. Catal. A 477 (2014) 
$54-63$.

[33] E. Moretti, M. Lenarda, L. Storaro, A. Talon, R. Frattini, S. Polizzi, E. Rodríguez-Castellón, A. Jiménez-López, Appl. Catal. B 72 (2007) 149-156.

[34] A. Martinez-Arias, D. Gamarra, M. Fernandez-Garcia, A. Hornes, P. Bera, Zs. Koppany, Z. Schay, Catal. Today 143 (2009) 211-217.

[35] P.G. Harrison, I.K. Ball, W. Azelee, W. Daniell, D. Goldfarb, Chem. Mater. 12 (2000) $3715-3725$.

[36] R. Zhang, J.T. Miller, C.D. Baertsch, J. Catal. 294 (2012) 69-78.

[37] R. Si, J. Raitano, N. Yi, L. Zhang, S.W. Chan, M. Flytzani-Stephanopoulos, Catal. Today 180 (2012) 68-80.

[38] W.W. Wang, P.P. Du, S.H. Zou, H.Y. He, R.X. Wang, Z. Jin, S. Shi, Y.Y. Huang, R. Si, Q.S. Song, C.J. Jia, C.H. Yan, ACS Catal. 5 (2015) 2088-2099.

[39] J.I. Langford, J. Appl. Cryst. 4 (1971) 259-260.

[40] J.I. Langford, J. Appl. Cryst. 6 (1973) 190-196.

[41] A.I. Frenkel, Q. Wang, N. Marinkovic, J.G. Chen, L. Barrio, R. Si, A.L. Cámara, A.M. Estrella, J.A. Rodriguez, J.C. Hanson, J. Phys. Chem. C 115 (2011) 17884-17890.

[42] A. Pfau, K.D. Schierbaum, Surf. Sci. 321 (1994) 71-80.

[43] R. Si, Y. Zhang, S. Li, B. Lin, C. Yan, J. Phys. Chem. B 108 (2004) 12481-12488.

[44] S. Zeng, X. Bai, X. Wang, W. Yu, Y. Liu, J. Rare Earths 24 (2006) 177-181.

[45] A. Martínez-Arias, A.B. Hungría, G. Munuera, D. Gamarra, Appl. Catal. B 65 (2006) 207-216.

[46] D.C. Frost, A. Ishitani, C.A. McDowell, Mol. Phys. 24 (1972) 861-877.

[47] P. Gawade, B. Mirkelamoglu, U.S. Ozkan, J. Phys. Chem. C 114 (2010) 18173-18181.

[48] L.S. Kau, D.J. Spira-Solomon, J.E. Penner-Hahn, K.O. Hodgson, E.I. Solomon, J. Am. Chem. Soc. 109 (1987) 6433-6442.

[49] J.E. Penner-Hahn, Coord. Chem. Rev. 249 (2005) 161-177.

[50] Q. Fu, A. Weber, M. Flytzani-Stephanopoulos, Catal. Lett. 77 (2001) 87-95.

[51] A. Aboukais, A. Bennani, C. Lamonier-Dulongpont, E. Abi-Aad, G. Wrobel, Colloids Surf. A 115 (1996) 171-177.

[52] W. Liu, M. Flytzani-Stephanopoulos, Chem. Eng. J. 64 (1996) 283-294.

[53] L. Kundakovic, M. Flytzani-Stephanopoulos, Appl. Catal. A 171 (1998) 13-29.

[54] X. Zheng, X. Zhang, X. Wang, S. Wang, S. Wu, Appl. Catal. A 295 (2005) 142-149.

[55] G. Avgouropoulos, T. Ioannides, H. Matralis, Appl. Catal. B 56 (2005) 87-93. 
[56] G.R. Rao, H.R. Sahu, B.G. Mishra, Colloids Surf. A 220 (2003) 261-269.

[57] F. Mariño, G. Baronetti, M. Laborde, A. Le Valant, N. Bion, F. Epron, D. Duprez, Int. J. Hydrogen Energy 33(4) (2008) 1345-1353. 
Table 1. Bulk copper concentrations $\left(\mathrm{Cu}_{\text {bulk }}\right)$, surface copper concentrations $\left(\mathrm{Cu}_{\text {surf }}\right)$, BET specific surface areas $\left(S_{\mathrm{BET}}\right)$, lattice constants of $\mathrm{CeO}_{2}(a)$ and averaged particle size $(D)$ of copper-ceria catalysts.

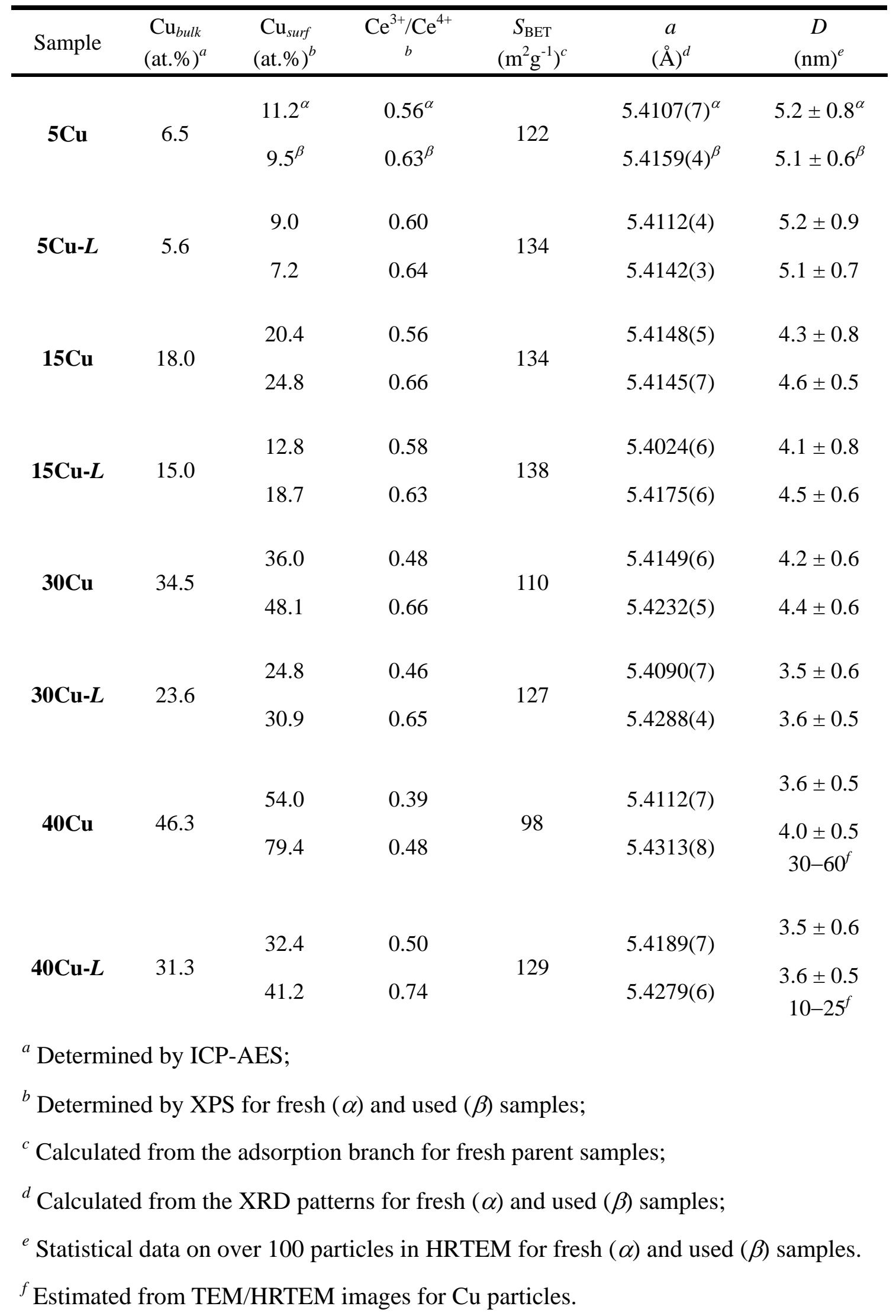


Table 2. XANES analysis and EXAFS fitting results ( $R$ : distance; $\mathrm{CN}$ : coordination number) on $\mathrm{Cu}-\mathrm{O}$ and $\mathrm{Cu}-\mathrm{Cu}$ shells of copper-ceria catalysts.

\begin{tabular}{|c|c|c|c|c|c|c|c|}
\hline \multirow{2}{*}{ Sample } & \multicolumn{3}{|c|}{ Molar fraction $(\%)^{a}$} & \multicolumn{2}{|c|}{$\mathrm{Cu}-\mathrm{O}^{b}$} & \multicolumn{2}{|c|}{$\mathrm{Cu}-\mathrm{Cu}^{c}$} \\
\hline & $\mathrm{Cu}^{0}$ & $\mathrm{Cu}^{+}$ & $\mathrm{Cu}^{2+}$ & $R(\AA)$ & $\mathrm{CN}$ & $R(\AA)$ & $\mathrm{CN}$ \\
\hline $\mathrm{Cu}$ & - & - & - & - & 一 & 2.558 & 12 \\
\hline $\mathrm{Cu}_{2} \mathrm{O}$ & - & - & - & 1.849 & 4 & 3.698 & 8 \\
\hline $\mathrm{CuO}$ & - & - & - & $\begin{array}{l}1.906 \\
1.985\end{array}$ & $\begin{array}{l}2 \\
2\end{array}$ & 2.912 & 4 \\
\hline \multirow{2}{*}{$5 \mathrm{Cu}$} & $0^{\alpha}$ & $0^{\alpha}$ & $100^{\alpha}$ & $1.94 \pm 0.01^{\alpha}$ & $3.6 \pm 0.2^{\alpha}$ & \multirow[t]{2}{*}{ - - } & \\
\hline & $0^{\beta}$ & $0^{\beta}$ & $100^{\beta}$ & $1.93 \pm 0.01^{\beta}$ & $3.0 \pm 0.2^{\beta}$ & & \\
\hline \multirow{2}{*}{$5 \mathrm{Cu}-L$} & 0 & 0 & 100 & $1.93 \pm 0.01$ & $3.4 \pm 0.3$ & \multirow[t]{2}{*}{ - } & \multirow[t]{2}{*}{ - } \\
\hline & 0 & 0 & 100 & $1.93 \pm 0.01$ & $3.3 \pm 0.2$ & & \\
\hline \multirow{2}{*}{$15 \mathrm{Cu}$} & 0 & 0 & 100 & $1.93 \pm 0.01$ & $3.4 \pm 0.2$ & \multirow[t]{2}{*}{ - } & \multirow[t]{2}{*}{ - } \\
\hline & 5 & 2 & 93 & $1.93 \pm 0.01$ & $2.7 \pm 0.2$ & & \\
\hline \multirow{2}{*}{$15 \mathrm{Cu}-\mathrm{L}$} & 0 & 0 & 100 & $1.93 \pm 0.01$ & $3.2 \pm 0.2$ & \multirow[t]{2}{*}{ _- } & \\
\hline & 5 & 0 & 95 & $1.93 \pm 0.01$ & $2.8 \pm 0.2$ & & \\
\hline \multirow{2}{*}{$30 \mathrm{Cu}$} & 0 & 0 & 100 & $1.93 \pm 0.01$ & $3.3 \pm 0.5$ & \multirow[t]{2}{*}{$\ldots$} & \\
\hline & 10 & 17 & 73 & $1.92 \pm 0.01$ & $2.9 \pm 0.6$ & & \\
\hline \multirow{2}{*}{$30 \mathrm{Cu}-\mathrm{L}$} & 0 & 0 & 100 & $1.94 \pm 0.01$ & $2.7 \pm 0.2$ & \multirow[t]{2}{*}{ - } & \multirow[t]{2}{*}{ - - } \\
\hline & 14 & 17 & 69 & $1.93 \pm 0.02$ & $2.3 \pm 0.6$ & & \\
\hline \multirow{2}{*}{$40 \mathrm{Cu}$} & 0 & 0 & 100 & $1.94 \pm 0.01$ & $3.2 \pm 0.2$ & -— & -— \\
\hline & 36 & 17 & 47 & $1.92 \pm 0.02$ & $1.9 \pm 0.3$ & $2.56 \pm 0.01$ & $3.4 \pm 0.8$ \\
\hline \multirow{2}{*}{$40 \mathrm{Cu}-\mathrm{L}$} & 0 & 0 & 100 & $1.94 \pm 0.01$ & $3.6 \pm 0.3$ & - - & -— \\
\hline & 28 & 8 & 64 & $1.91 \pm 0.01$ & $2.4 \pm 0.4$ & $2.56 \pm 0.01$ & $2.6 \pm 0.7$ \\
\hline
\end{tabular}

${ }^{a}$ For fresh $(\alpha)$ and used $(\beta)$ samples determined by XANES linear combination analysis with the $\mathrm{Cu}, \mathrm{Cu}_{2} \mathrm{O}$ and $\mathrm{CuO}$ references.

${ }^{b}$ For fresh $(\alpha)$ and used $(\beta)$ samples by $1^{\text {st }}$ shell approximate model;

${ }^{c}$ For fresh $(\alpha)$ and used $(\beta)$ samples by metallic $\mathrm{Cu}$ model. 
Table 3. $\mathrm{H}_{2}$-TPR reduction temperatures $\left(T_{\mathrm{R}}\right)$ and $\mathrm{H}_{2}$ consumption $\left(H_{2}\right)$ of copper-ceria catalysts.

\begin{tabular}{ccc}
\hline Sample & $\begin{array}{c}T_{\mathrm{R}} \\
\left({ }^{\circ} \mathrm{C}\right)\end{array}$ & $\begin{array}{c}H_{2} \\
(\mu \mathrm{mol} / \mathrm{g})\end{array}$ \\
\hline $\mathbf{5 C u}$ & $174^{a}, 219^{b}$ & $428^{a}, 672^{b}\left(1100^{d}, 391^{e}\right)$ \\
$\mathbf{5 C u}-\mathbf{L}$ & $200^{a}, 249^{c}, 277^{b}$ & $489^{a}, 132^{c}, 426^{b}(1047,335)$ \\
$\mathbf{1 5 C u}$ & $155^{a}, 171^{b}$ & $804^{a}, 761^{b}(1565,1158)$ \\
$\mathbf{1 5 C u} \boldsymbol{L}$ & $125^{c}, 173^{a}, 198^{b}$ & $119^{c}, 794^{a}, 886^{b}(1799,948)$ \\
$\mathbf{3 0 C u}$ & $148^{a}, 174^{b}$ & $1692^{a}, 1376^{b}(3068,2461)$ \\
$\mathbf{3 0 C u} \boldsymbol{L}$ & $111^{c}, 157^{a}, 173^{b}$ & $87^{c}, 1081^{a}, 1003^{b}(2171,1570)$ \\
$\mathbf{4 0 C u}$ & $149^{a}, 180^{b}$ & $1457^{a}, 2455^{b}(3912,3582)$ \\
$\mathbf{4 0 C u} \boldsymbol{L}$ & $110^{c}, 145^{a}, 172^{b}$ & $192^{c}, 760^{a}, 1680^{b}(2632,2187)$ \\
& \\
W-temperature reduction; & \\
gh-temperature reduction;
\end{tabular}




\section{Figure Captions}

Scheme 1. Evolutions of different copper species during the leaching, reduction or reaction processes.

Figure 1. $\mathrm{CO}$ conversion and $\mathrm{O}_{2}$ selectivity as a function of reaction temperature during CO-PROX over copper-ceria catalysts: (a) $5 \mathrm{Cu}$ and $\mathbf{5 C u}-\boldsymbol{L}$; (b) $15 \mathrm{Cu}$ and $15 \mathrm{Cu}-L$; (c) 30Cu and 30Cu- $L$; (d) $40 \mathrm{Cu}$ and $40 \mathrm{Cu}-L$.

Figure 2. XRD patterns of copper-ceria catalysts: (a) Fresh; (b) Used.

Figure 3. TEM (1) and HRTEM (2) images, together with the related particle size-distribution histograms (3) of fresh copper-ceria samples: (a) $\mathbf{5 C u}$; (b) $\mathbf{5} \mathbf{C u}-\boldsymbol{L}$; (c) $15 \mathrm{Cu}$; (d) $15 \mathrm{Cu}-L$; (e) $30 \mathrm{Cu}$; (f) $30 \mathrm{Cu}-L$; (g) $40 \mathrm{Cu}$; (h) $40 \mathrm{Cu}-L$.

Figure 4. TEM (1) and HRTEM (2) images, together with the related particle size-distribution histograms (3) of used copper-ceria samples: (a) $\mathbf{5 C u}$; (b) $\mathbf{5 C u}-\mathbf{L}$; (c) $15 \mathrm{Cu}$; (d) $15 \mathrm{Cu}-L$; (e) $30 \mathrm{Cu}$; (f) $30 \mathrm{Cu}-L$; (g) $40 \mathrm{Cu}$; (h) $40 \mathrm{Cu}-L$.

Figure 5. HAADF-STEM EDS mapping results for copper-ceria catalysts: (a) 30Cu, fresh; (b) 30Cu- $L$, fresh; (c) 30Cu, used; (d) 30Cu- $L$, used.

Figure 6. Averaged particle size and lattice constants of $\mathrm{CeO}_{2}$ for copper-ceria catalysts as a function of bulk $\mathrm{Cu}$ concentration: (a) Parent; (b) Leached.

Figure 7. $\mathrm{Cu}$ K-edge XANES profiles of copper-ceria catalysts: (a) $\mathbf{5 C u}$ and $\mathbf{5 C u}-\boldsymbol{L}$; (b) $15 \mathrm{Cu}$ and $15 \mathrm{Cu}-L$; (c) $30 \mathrm{Cu}$ and $30 \mathrm{Cu}-L$; (d) $40 \mathrm{Cu}$ and $40 \mathrm{Cu}-L$.

Figure 8. EXAFS fitting results in $R$ space for copper-ceria catalysts: (a) $\mathbf{5 C u}$ and 5Cu- $L$; (b) $15 \mathrm{Cu}$ and $15 \mathrm{Cu}-L$; (c) $30 \mathrm{Cu}$ and $30 \mathrm{Cu}-L$; (d) $40 \mathrm{Cu}$ and $40 \mathrm{Cu}-L$. 
Figure 9. Ce 3d XPS spectra for copper-ceria catalysts: (a) $\mathbf{5 C u}$ and $\mathbf{5 C u}-\boldsymbol{L}$; (b) $\mathbf{1 5 C u}$ and $15 \mathrm{Cu}-L$; (c) $30 \mathrm{Cu}$ and $30 \mathrm{Cu}-L$; (d) $40 \mathrm{Cu}$ and $40 \mathrm{Cu}-L$.

Figure 10. $\mathrm{H}_{2}$-TPR profiles of parent (solid) and leached (dash) copper-ceria catalysts. Labels represent the reduction of highly dispersed $\mathrm{CuO}_{x}$ clusters (A) and strongly bound $\mathrm{Cu}-\left[\mathrm{O}_{x}\right]-\mathrm{Ce}$ structure $(\mathrm{B})$. 
Scheme 1.

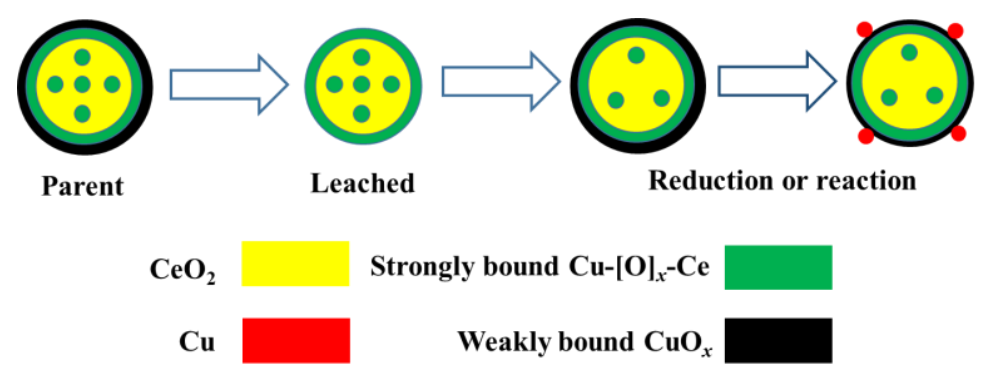

Scheme 1. Evolutions of different copper species during the leaching, reduction or reaction processes. 

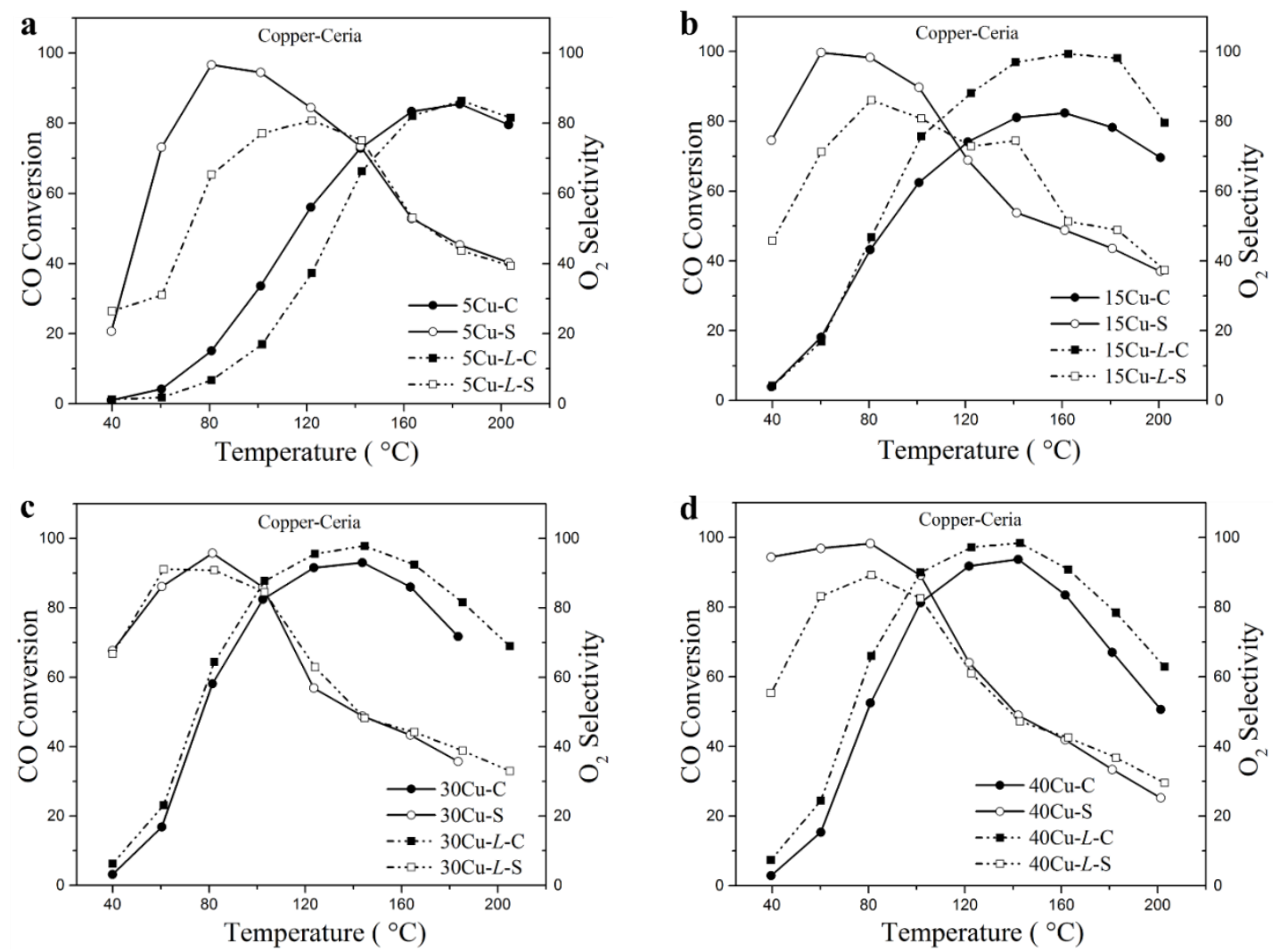

Figure 1. $\mathrm{CO}$ conversion and $\mathrm{O}_{2}$ selectivity as a function of reaction temperature during CO-PROX over copper-ceria catalysts: (a) $\mathbf{5 C u}$ and $\mathbf{5 C u}-\boldsymbol{L}$; (b) $15 \mathrm{Cu}$ and $15 \mathrm{Cu}-L$; (c) 30Cu and 30Cu- $L$; (d) $40 \mathrm{Cu}$ and $40 \mathrm{Cu}-L$. 

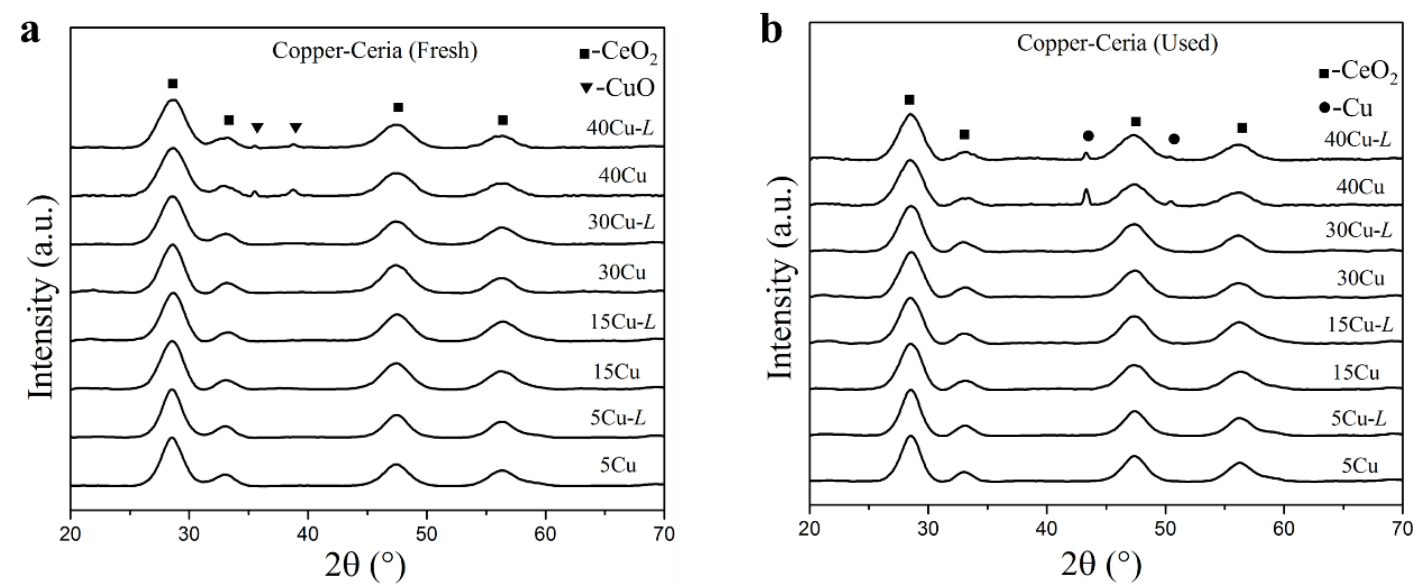

Figure 2. XRD patterns of copper-ceria catalysts: (a) Fresh; (b) Used. 

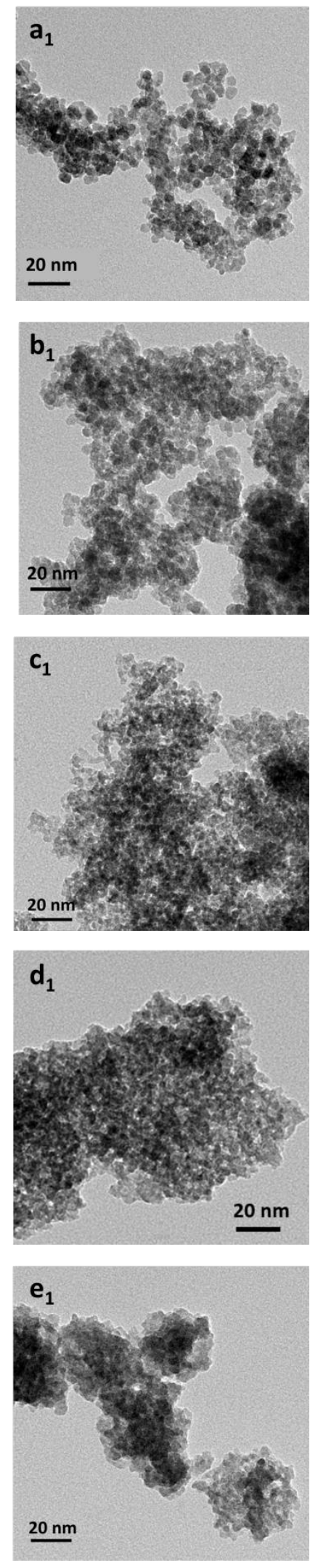
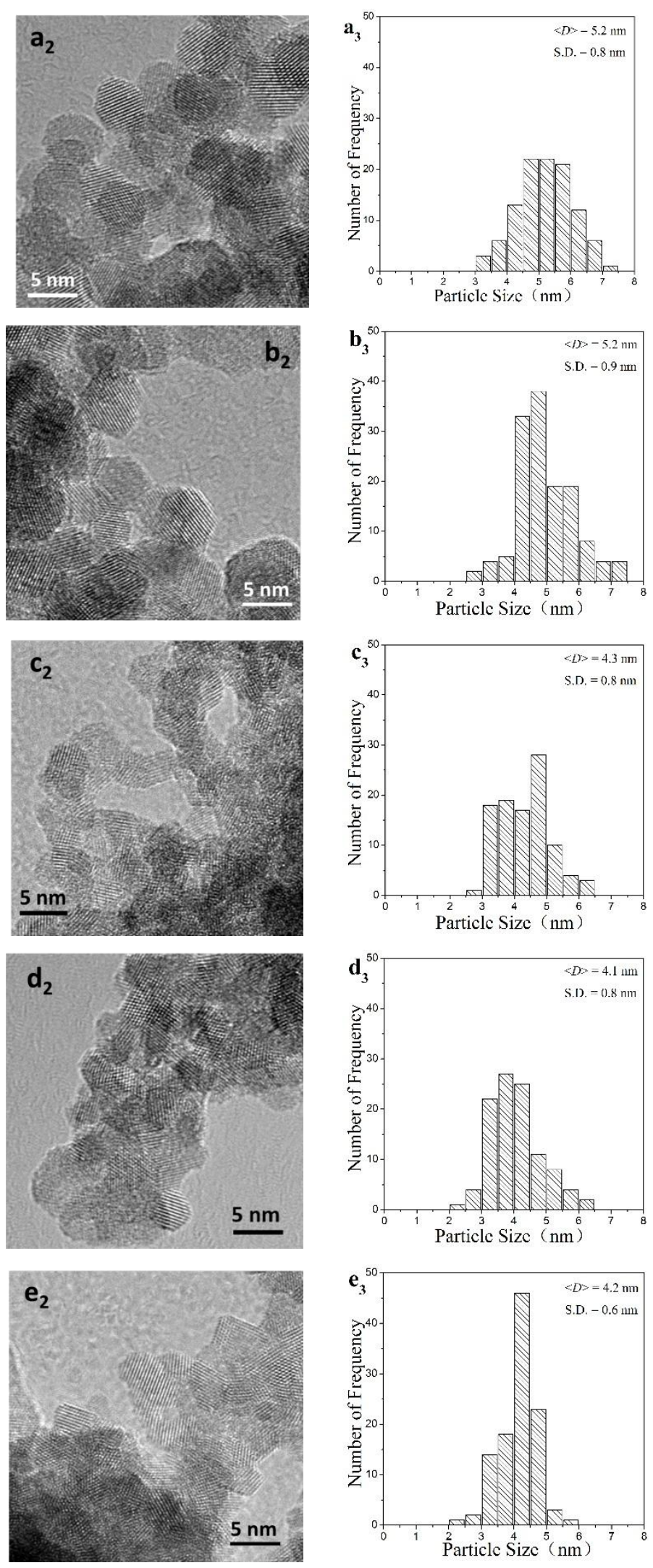

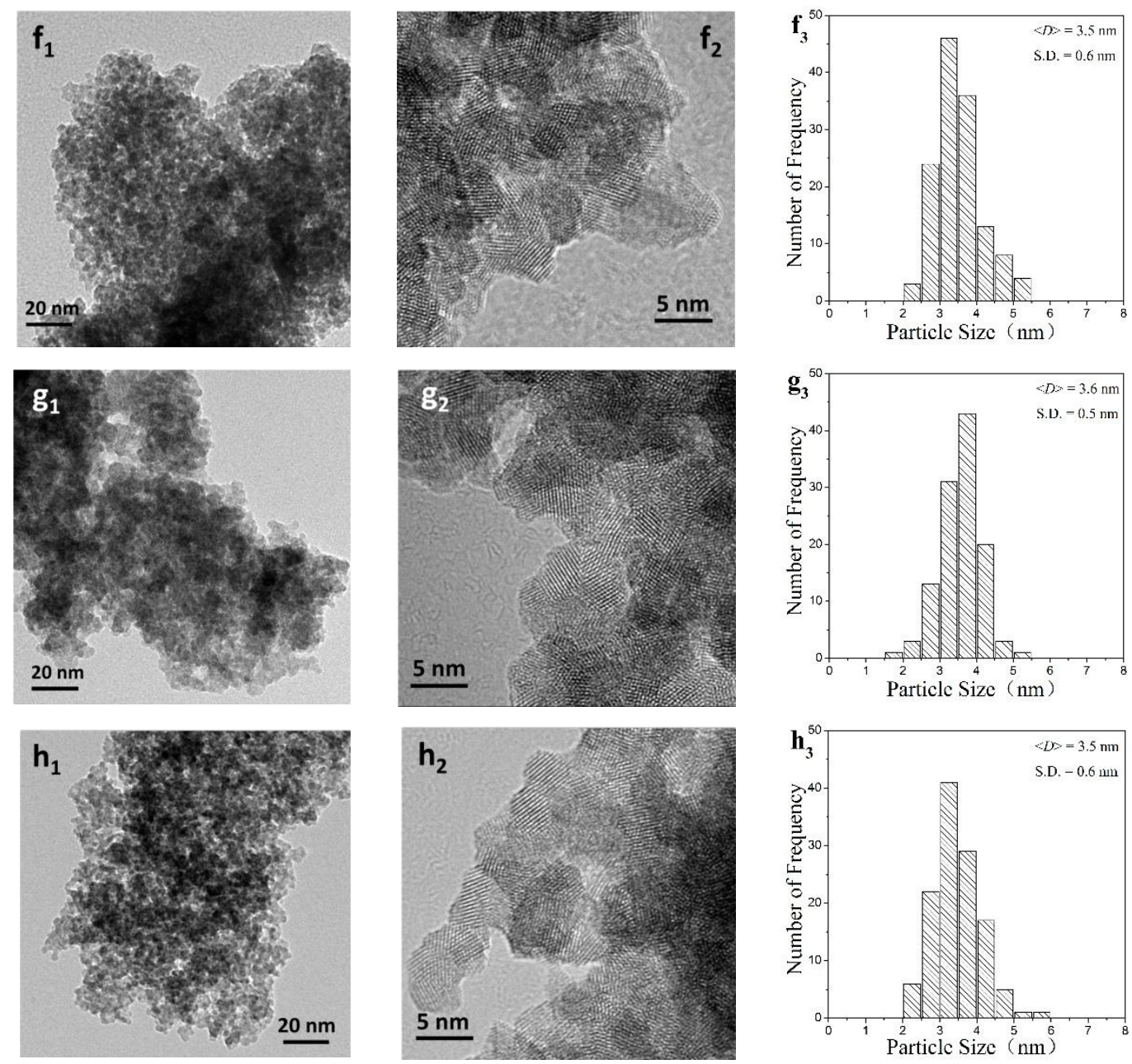

Figure 3. TEM (1) and HRTEM (2) images, together with the related particle size-distribution histograms (3) of fresh copper-ceria samples: (a) $\mathbf{5 C u}$; (b) $\mathbf{5} \mathbf{C u}-\boldsymbol{L}$; (c) $15 \mathrm{Cu}$; (d) 15Cu- $L$; (e) 30Cu; (f) 30Cu-L; (g) 40Cu; (h) 40Cu- $L$. 

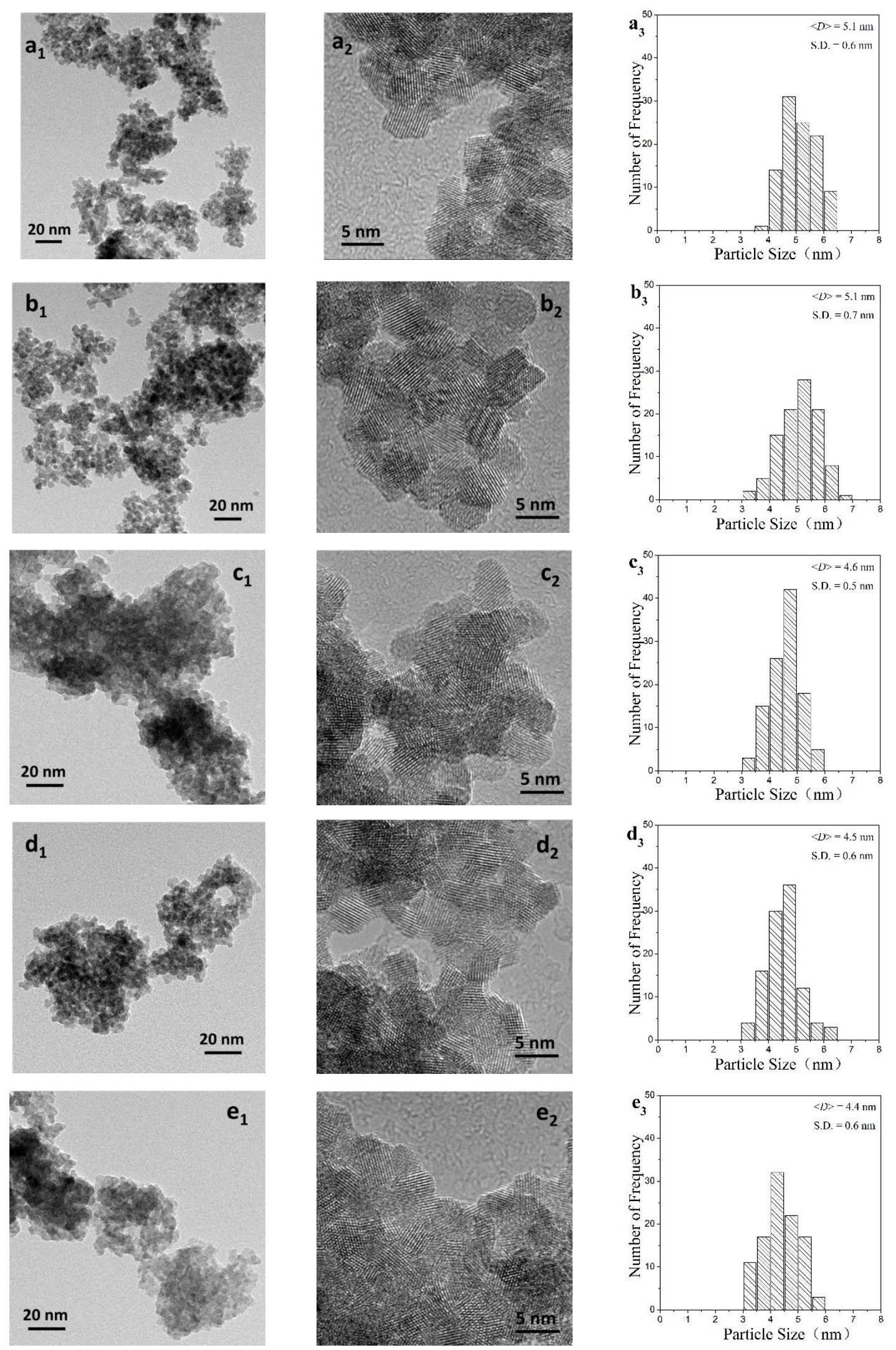

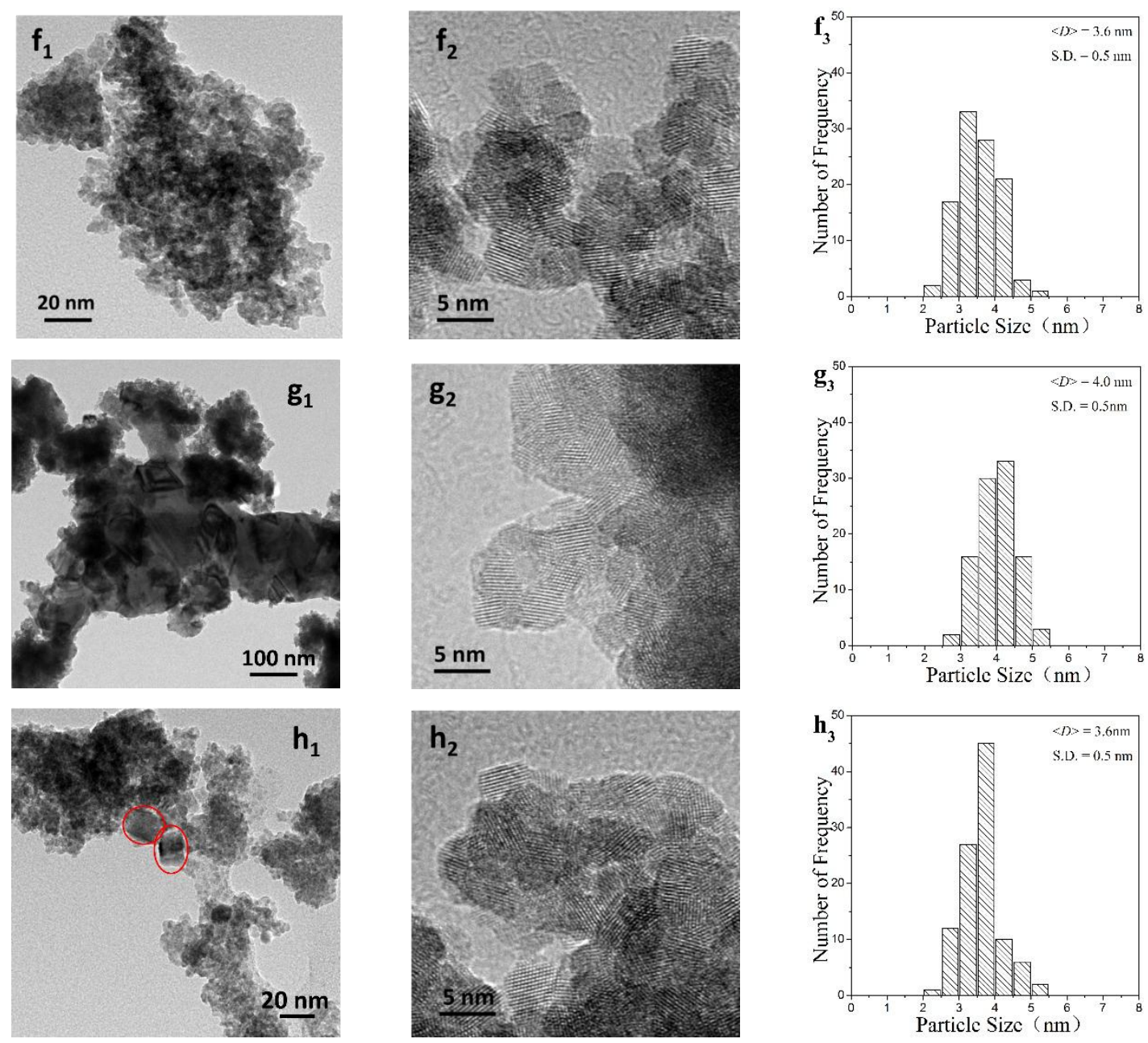

Figure 4. TEM (1) and HRTEM (2) images, together with the related particle size-distribution histograms (3) of used copper-ceria samples: (a) $\mathbf{5 C u}$; (b) $\mathbf{5 C u} \mathbf{C}$; (c) $15 \mathrm{Cu}$; (d) $15 \mathrm{Cu}-L$; (e) $30 \mathrm{Cu}$; (f) $30 \mathrm{Cu}-L$; (g) $40 \mathrm{Cu}$; (h) $40 \mathrm{Cu}-L$. 

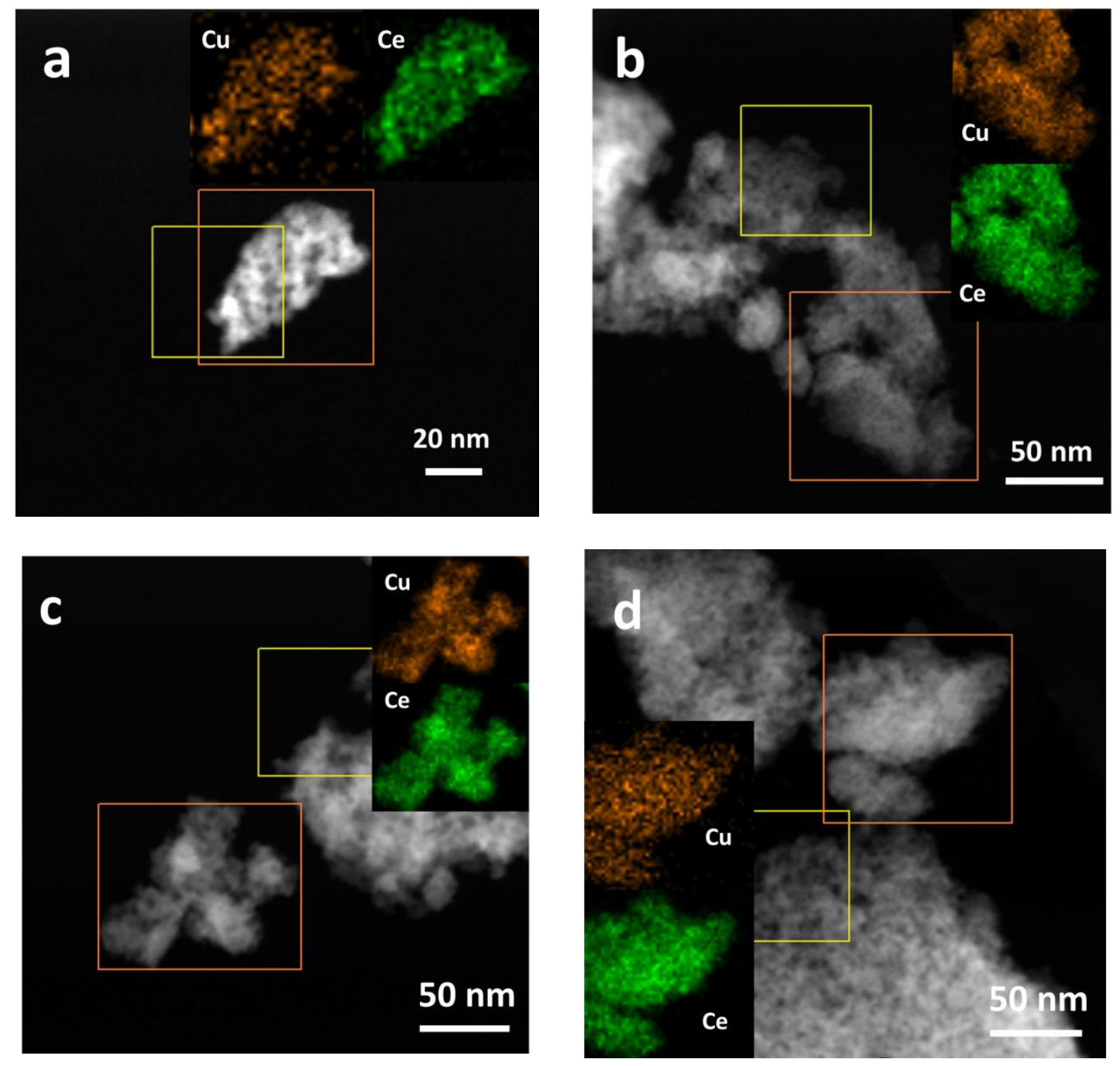

Figure 5. HAADF-STEM EDS mapping results for copper-ceria catalysts: (a) 30Cu, fresh; (b) 30Cu- $L$, fresh; (c) $30 \mathrm{Cu}$, used; (d) $30 \mathrm{Cu}-\boldsymbol{L}$, used. 

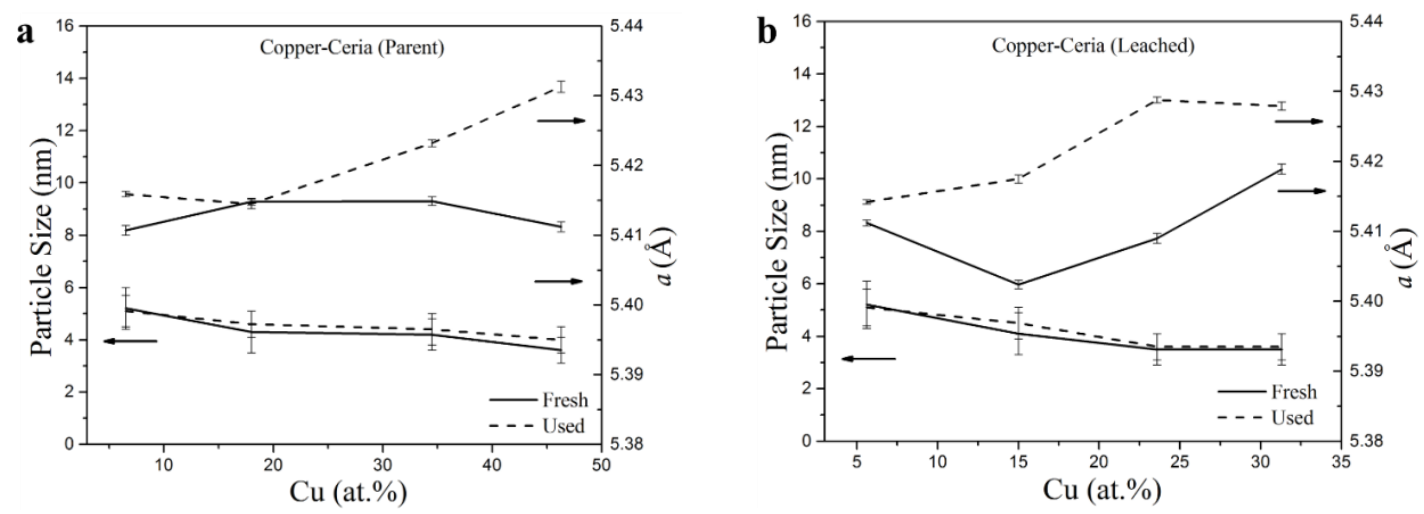

Figure 6. Averaged particle size and lattice constants of $\mathrm{CeO}_{2}$ for copper-ceria catalysts as a function of bulk $\mathrm{Cu}$ concentration: (a) Parent; (b) Leached. 

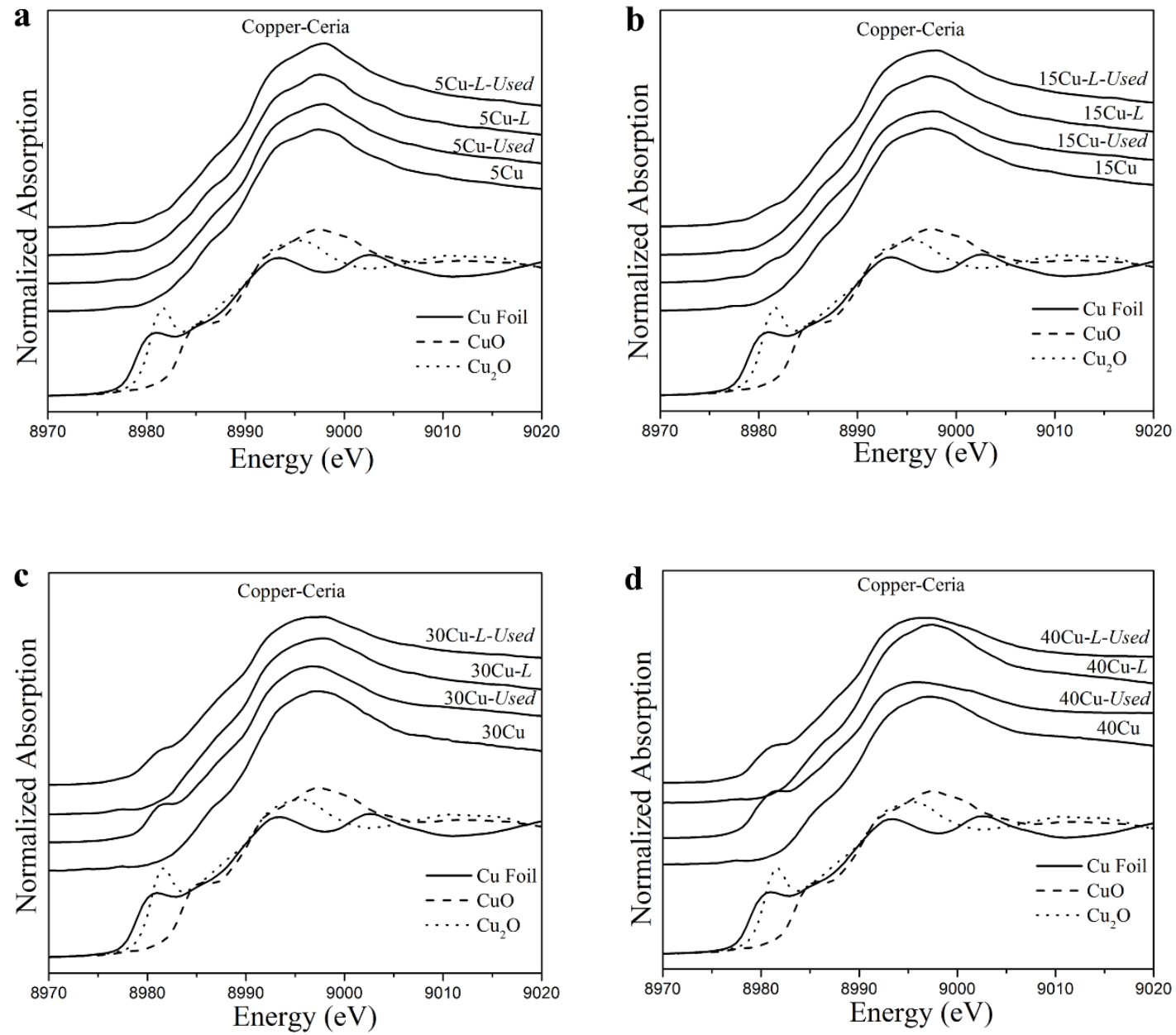

Figure 7. $\mathrm{Cu}$ K-edge XANES profiles of copper-ceria catalysts: (a) $\mathbf{5 C u}$ and $\mathbf{5 C u} \mathbf{C}$;

(b) $15 \mathrm{Cu}$ and $15 \mathrm{Cu}-L$; (c) $30 \mathrm{Cu}$ and $30 \mathrm{Cu}-L$; (d) $40 \mathrm{Cu}$ and $40 \mathrm{Cu}-L$. 

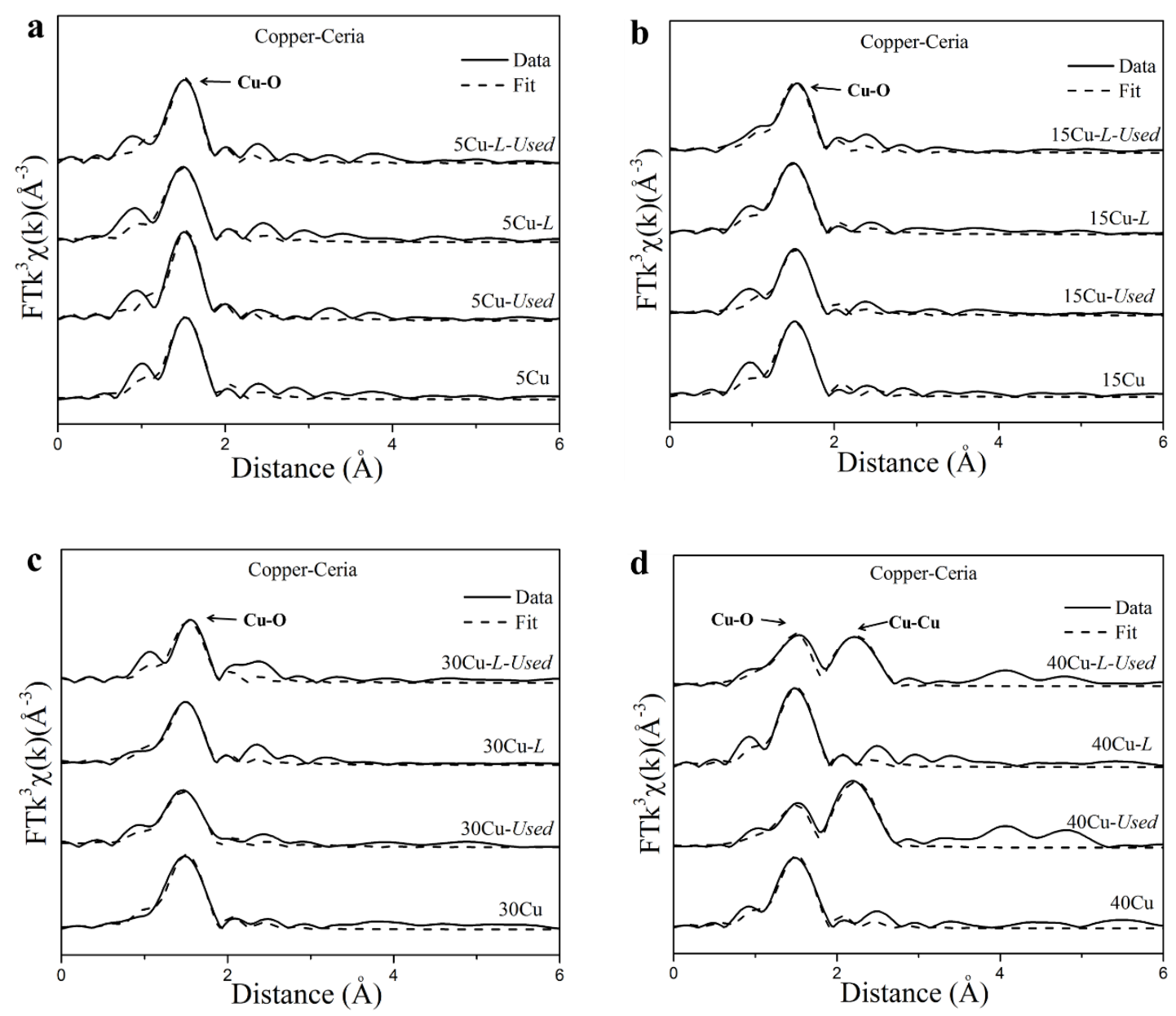

Figure 8. EXAFS fitting results in $R$ space for copper-ceria catalysts: (a) 5Cu and 5Cu- $L$; (b) $15 \mathrm{Cu}$ and $15 \mathrm{Cu}-L$; (c) $30 \mathrm{Cu}$ and $30 \mathrm{Cu}-L$; (d) $40 \mathrm{Cu}$ and $40 \mathrm{Cu}-L$. 

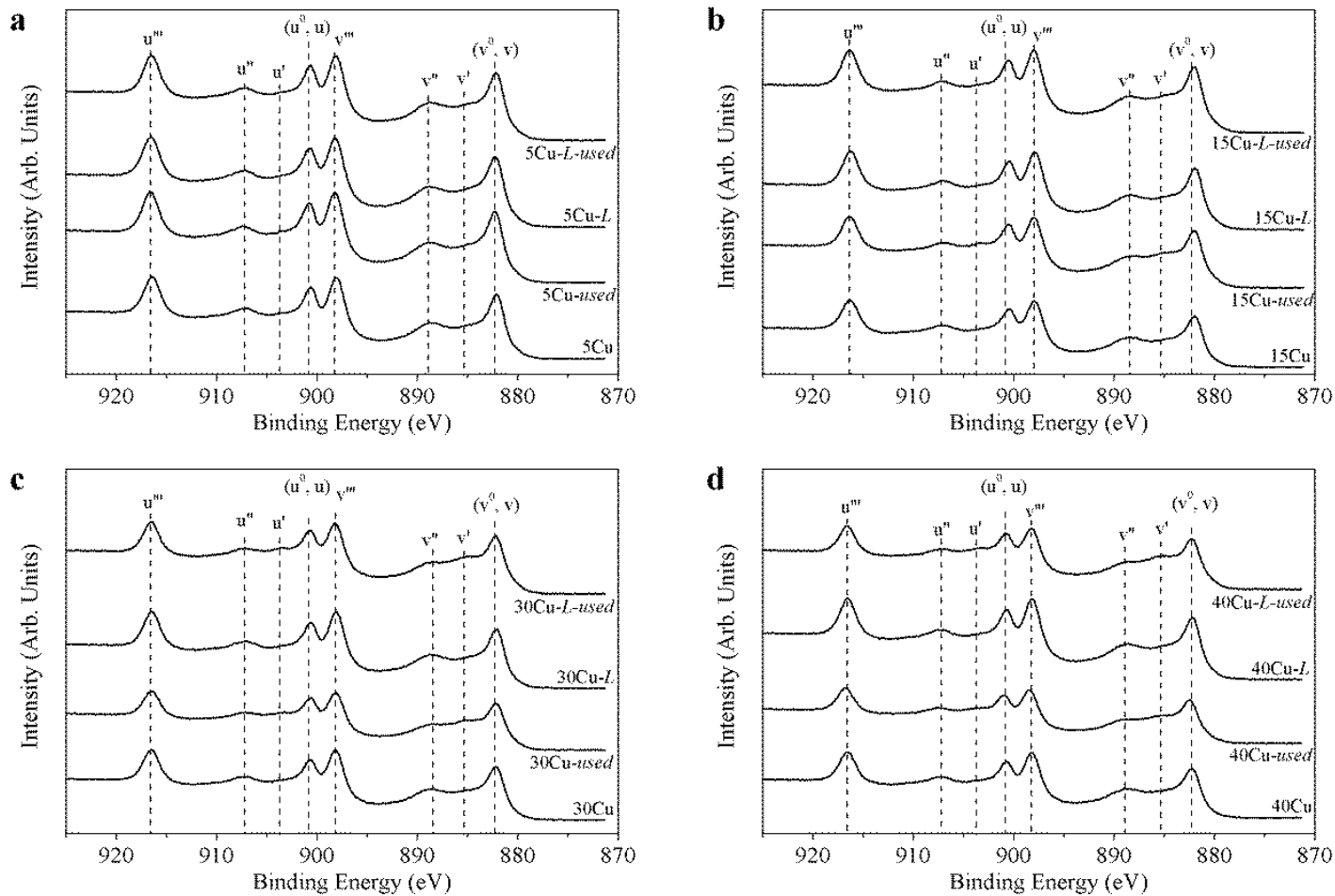

Figure 9. Ce 3d XPS spectra for copper-ceria catalysts: (a) $\mathbf{5 C u}$ and $\mathbf{5 C u}-\boldsymbol{L}$; (b) $\mathbf{1 5 C u}$ and $15 \mathrm{Cu}-L$; (c) $30 \mathrm{Cu}$ and $30 \mathrm{Cu}-L$; (d) $40 \mathrm{Cu}$ and $40 \mathrm{Cu}-L$. 


\section{Graphical abstracts}

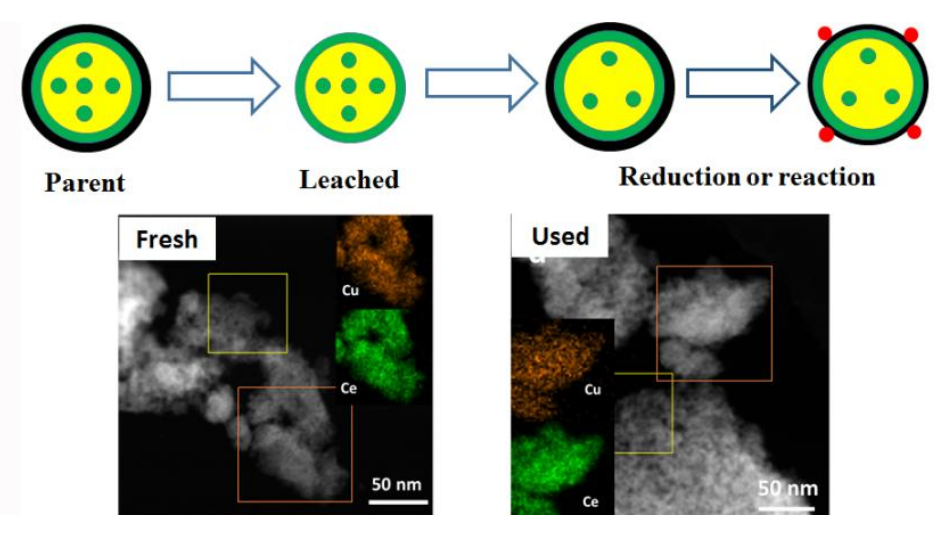

Ammonium carbonate leaching was applied to the coprecipitated copper-ceria. Both parent and leached catalysts up to 30 at.\% Cu included uniform copper species in ceria. Fully oxidized $\mathrm{Cu}^{2+}$ component in fresh samples and metallic copper for used catalysts of 30-40 at.\% Cu were verified. High and stable PROX reactivity appeared for 30 at.\% Cu. It has been demonstrated that strongly bound $\mathrm{Cu}-[\mathrm{O}]_{x}-\mathrm{Ce}$ structure is the reservoir for surface active copper sites, and can recover weakly bound $\mathrm{CuO}_{x}$ clusters on the $\mathrm{CeO}_{2}$ surface. 